NBER WORKING PAPER SERIES

\title{
THE IMPACT OF SOCIAL POLICY AND ECONOMIC ACTIVITY THROUGHOUT THE FERTILITY DECISION TREE
}

\author{
Phillip B. Levine \\ Working Paper 9021 \\ http://www.nber.org/papers/w9021 \\ NATIONAL BUREAU OF ECONOMIC RESEARCH \\ 1050 Massachusetts Avenue \\ Cambridge, MA 02138 \\ June 2002
}

I would like to thank Ted Joyce, Melissa Kearney, Erzo Luttmer, and Doug Staiger for comments on an earlier draft, participants of seminars at the Joint Center for Poverty Research and the National Bureau of Economic Research Children's Program Meeting for their comments, and Chris Rogers for his help compiling the NSFG data. This paper evolved from an earlier project with Diane Whitmore. The views expressed herein are those of the author and not necessarily those of the National Bureau of Economic Research.

(C) 2002 by Phillip B. Levine. All rights reserved. Short sections of text, not to exceed two paragraphs, may be quoted without explicit permission provided that full credit, including (C) notice, is given to the source. 
The Impact of Social Policy and Economic Activity Throughout the Fertility Decision Tree Phillip B. Levine

NBER Working Paper No. 9021

June 2002

JEL No. I18, I38, J13

\begin{abstract}
This paper considers the impact of changes in abortion and welfare policies along with economic conditions over the 1985 to 1996 period at each stage of the fertility decision tree, including sexual activity, contraception, pregnancy, abortion, and birth. Examining the impact of policy at each stage of the decision tree represents a useful approach because consistent findings provide stronger evidence of a causal link than focusing on just one stage. The abortion policies considered are parental involvement laws and mandatory waiting periods; welfare policies include benefit generosity as well as state-level welfare waivers as a whole and the "family cap." State-level data over this period are used to examine abortion, birth, and pregnancy outcomes, while microdata from the 1988 and 1995 National Surveys of Family Growth are employed to examine sexual activity and contraception. For those policies that target certain subgroups of the population, estimates are provided separately for each group and compared to help further identify causality. I find that parental involvement laws increase contraception use among minors, leading to fewer pregnancies and, therefore, fewer abortions; teen births do not rise in response. Evidence regarding welfare policies does not consistently support any impact throughout the decision tree.
\end{abstract}

\author{
Phillip B. Levine \\ Department of Economics \\ Wellesley College \\ Wellesley, MA 02481 \\ and NBER \\ plevine@wellesley.edu
}


Research that examines the factors which affect a woman's fertility behavior frequently restricts its attention to the final node of a decision tree, giving birth. But that outcome depends upon a series of preceding decisions. A woman and her partner initially decide whether to engage in sexual activity and whether to use contraception; the outcome of these decisions alters the probability of becoming pregnant. If pregnant, they must decide whether or not to carry the pregnancy to term or to abort the pregnancy. The birth only occurs if specific paths along the decision tree are followed and no spontaneous abortion occurs.

A thorough analysis of the factors affecting fertility outcomes would benefit from an analysis of the factors affecting all of the stages of this decision tree. To the extent that empirical research shows that a particular policy change appears to affect fertility, that finding could be considerably strengthened if it is also found to affect the preceding decisions in a manner consistent with the impact on births. Moreover, such an approach would also help identify the stage of the decision tree where altered behavior resulted in the impact on births.

Recent research has begun to move in this direction, particularly in the area of the impact of abortion policy. As I review below, recent work has explored the impact of policy changes such as Medicaid funding restrictions and parental involvement laws on pregnancies, abortions, and births, but these behaviors still only represent the second half of the full decision tree. No work of which I am aware has simultaneously explored the impact on the full set of decisions involved in a birth outcome. An important contribution of this paper will be to undertake such an exercise.

The determinants of fertility and its precedents that I will consider include a set of welfare and abortion policy changes as well as changes in economic activity over the 1985 to 1996 period. The early to mid 1990s, in particular, was a period of rapid changes in social policy. Although 
national welfare reform legislation was not enacted until 1996, the reform process began at the state level a few years earlier than that in the form of waivers granted to states from the federal government. The generosity of welfare benefits also plummeted over this period. In addition, the 1992 U.S. Supreme Court decision in Planned Parenthood of Southeastern Pennsylvania v. Casey reaffirmed the legality of abortion, but allowed for its access to be restricted so long as it did not pose an "undue burden." The court ruled that provisions requiring parental involvement by teens and mandatory waiting periods before an abortion can be performed were not too burdensome and some states implemented these restrictions subsequently. The economy also moved from boom to bust and returned to boom again over the course of this period. Each of these changes have implications for fertility and the decisions which lead up to it; this study will examine these relationships.

To undertake this exercise, I will take advantage of cross-state variation in policies and economic conditions using data from multiple sources. Working up the decision tree, I will utilize data on births from Vital Statistics, on abortions from the Alan Guttmacher Institute, and on contraception and sexual activity from the 1988 and 1995 National Survey of Family Growth. Methodologically, the analysis will estimate regression models of each outcome as a function of the policies and economic conditions as well as state and year fixed effects and, in some specifications, state-specific trends. This approach provides difference-in-difference estimates of the impact of each policy change and of changes in economic activity. Where appropriate, the population will be divided into subgroups where a particular policy is targeted at one of the groups, but should have no impact on the other to help identify whether the estimated relationships are truly causal.

The results indicate that parental involvement laws have a consistent impact on behavior throughout the fertility decision tree. They are found to reduce abortions for minors, but not older 
women, although they have no significant positive impact on births. The reduction in pregnancies among teens is supported by an increase in contraceptive use, but not a reduction in sexual activity, in response to a parental involvement law. Otherwise, the evidence does not support a consistent effect of welfare policies or economic activity throughout the decision tree. I also find that pregnancies and births are procyclical, driven by changes in contraceptive use among unmarried women.

\section{BACKGROUND}

This paper will focus on the impact of a number of changes in welfare and abortion policy as well as changes in economic activity between 1985 and 1996. This section of the paper will provide some background on the policy changes to provide a better understanding of how they can be used to identify the statistical models reported below.

National welfare reform was enacted in 1996 and included time limits on benefit receipt and work participation goals that states need to meet, among other provisions. Although these changes largely took place after the window considered for this analysis, similar changes were instituted at the state level in the years preceding national welfare reform. Beginning in 1992, the federal government began granting waivers to states to implement "experimental" welfare policies that otherwise contradicted existing federal requirements. ${ }^{1}$ Work requirements, time limits, and other policies designed to encourage work were a component of many of these waivers. By altering the

${ }^{1}$ Waivers were also granted before 1992, but these policy changes were mainly restricted to small portions of a state's welfare population (cf. Levine and Whitmore, 1998) and will not be considered here. Even after 1992, some states were granted waivers that pertained to a small segment of their welfare population. In this analysis I focus on those major, statewide waivers granted starting in 1992, which are described in detail in Council of Economic Advisers (1997 and 1999) and in Crouse (1999). 
payoff of giving birth, as discussed below, these policy changes could have had an impact on fertility-related behavior. A policy known as a family cap was another important provision of many of the waivers granted to states that directly affected the cost of childbearing. Unlike traditional welfare benefits, which would rise if a mother on welfare conceived an additional child while collecting benefits, under a family cap her benefit level would remain unchanged.

Importantly, not all states received waivers; those that did implemented them at different times. Moreover, some states' waivers included family caps and others did not. The evolution of this process resulted in different states having different policies in place at different times that I will exploit in the empirical analysis reported below.

Table 1 reports the states that implemented waivers as well as those that included the family cap provision; Figure 1 displays the count of states that introduced waivers year-by-year. Between 1992 and 1995, 19 states implemented waivers, 10 of which included the family cap. These changes that took place in 1995 or earlier enable me to identify the statistical models reported here because these policies will be introduced with a lag, as described below.

Welfare reform through waivers granted to states was not the only change in welfare policy that was taking place over this period; welfare benefits were also becoming considerably less generous. States have always had the right to set their own benefit levels and the variation across states is quite large. But these levels are typically set in nominal dollars and do not automatically adjust over time with inflation. Over this period, many states let several years pass before implementing small benefit changes that did not recoup the lost value attributable to inflation. Other states instituted outright cuts in benefits. Nationwide, taking a population-weighted average of welfare benefits across states indicates that the real value of the maximum benefit for a family of 
three fell from $\$ 503$ in 1985 (measured in 1996 dollars) to $\$ 394$ in 1996, representing a 22 percent decline. Significant variation exists in the overall change across states from the beginning to the end of the period as well as year-to-year.

Several changes in abortion policy also took place over the sample period, assisted by the support for parental involvement and mandatory waiting period laws provided by the U.S. Supreme Court in the Casey decision. ${ }^{2}$ With a parental involvement law, a woman under age 18 would be required to notify and, in some cases, obtain consent from a parent before being able to obtain an abortion. Earlier court decisions on parental involvement provisions (particularly Planned Parenthood of Central Missouri v. Danforth, 1976; Bellotti v. Baird, 1979; City of Akron v. Akron Center for Reproductive Health, 1983; Planned Parenthood of Kansas City v. Ashcroft, 1983; and Ohio v. Akron Center for Reproductive Health, 1990) along with the Casey decision indicated that such a policy would be constitutional so long as the law allowed for "judicial bypass," in which a minor would be able to notify and potentially obtain the consent of a judge rather than her parent. The increasing clarity with which parental involvement laws would be deemed constitutional led to a trend towards more parental involvement laws, particularly beginning in 1989. Of the 29 states that had implemented these policies, 17 of them went into effect between 1989 and 1995 (see Table 1 and Figure 1).

Mandatory waiting period laws were even more dramatically influenced by the 1992 Casey decision. In fact, it reversed an earlier U.S. Supreme Court decision in Ohio v. Akron Center for Reproductive Health (1983) that had prohibited such laws. States began enacting mandatory waiting

${ }^{2}$ The other common policy restriction on abortion access are laws that prevent state Medicaid funds from being used to provide abortions. Because few states changed their policies in this regard over the sample period considered here, I do not examine their impact in this research. 
periods typically of 24 hours soon after they became constitutional. Between 1992 and 1995, 11 states had implemented them.

The final factor that I examine regarding its potential impact on fertility-related behavior is economic activity, measured using the female unemployment rate. The 1985 to 1996 period is one that is characterized by an expansion through the late 1980s followed by a recession in the early 1990s and another expansion following that through 1996 (and beyond). The unemployment rate for women started out at 7.4 percent in 1985 , declined to a minimum of 5.4 percent in 1989 , rose to a peek of 7.0 percent in 1992, and then fell to 5.4 percent in 1996. Variation exists across states at a point in time as well as in the trend over time that I utilize in the empirical work reported below.

\section{THEORETICAL CONSIDERATIONS}

Before I begin to report the empirical work conducted to estimate the relationship between these policy changes and changes in economic activity on fertility and its antecedent behavior, I describe what economic models would predict. Regarding the impact of abortion policy, Levine and Staiger (2002) derive the theoretical impact of abortion restrictions of varying magnitudes on the pregnancy, abortion, and birth decisions. Sexual activity and contraception are not distinguished, but predictions regarding pregnancy have obvious implications for the combination of these two types of behavior, if not for each one separately.

The basis of their model is a set of assumptions indicating that pregnancy reduction becomes increasingly costly the greater one's effort to avoid a pregnancy, that decisions regarding pregnancy, abortion, and birth are made sequentially, and that new information may be obtained between decision-making steps. Within the framework of this model, the decision to abort conditional upon being pregnant is straightforward: if the cost associated with an abortion is greater than the cost of 
having an unwanted child, a pregnant woman would abort. The pregnancy decision is more complicated because it is made in the context of uncertainty regarding the subsequent values of the payoffs if new information arrives. This new information could come in the form of the level of support for the pregnancy from the woman's partner or family, a change in the woman's or her partner's employment situation, or a fetal defect, among other things. Therefore, this decision is made by maximizing the expected payoff. The solution to this problem indicates that women should choose a level of pregnancy avoidance at which its marginal cost just equals its marginal benefit, measured as the expected payoff from avoiding a pregnancy.

Within this framework, abortion operates much like insurance. The availability of abortion protects women from giving birth to children who would be unwanted. If it is available at a very low cost (monetary and otherwise), however, then women may reduce their level of pregnancy avoidance, thereby increasing the likelihood that a pregnancy will result. These additional pregnancies are likely to lead to additional abortions, but may end in a birth if the information obtained once pregnant is favorable. Mandatory delay and parental involvement laws may be thought of as a small increase in the cost of abortion from levels that begin relatively low in an environment of legal abortion. If so, this model predicts that fewer pregnancies and fewer abortions will result, whereas births may either be unaffected or actually may even decline.

Welfare policies have different effects on fertility-related behavior because changes in these policies affect the payoff to giving birth rather than the cost of having an abortion. Nevertheless, the framework provided by Levine and Staiger (2002) can help address the predicted impact of changes in welfare policies. Predictions regarding birth are relatively straightforward and have been made by others previously (cf. Becker, 1981); a more generous welfare system reduces the cost of being 
a single parent, which should increase births. In the present context a more generous welfare system could mean increased benefit levels, or a world without the restrictions imposed by welfare reform.

Predictions regarding abortion, however, are more complicated. Conditional upon pregnancy, a more generous welfare system would lead some women to choose to give birth rather than abort (cf. Klerman, 1998). But changes in welfare generosity may also increase the number of women who become pregnant. Since the payoff from birth is now greater, women may reduce their level of pregnancy avoidance. In the Levine and Staiger (2002) model not all of these additional pregnancies will result in births. Those women who become pregnant will obtain new information regarding the payoff associated with childbirth, and choose to abort or give birth accordingly. Since some of these additional pregnancies may eventually be aborted, increased welfare generosity may increase the prevalence of abortions. The overall impact of welfare policies on abortion prevalence, therefore, is ambiguous.

The impact of economic conditions on fertility-related behavior is ambiguous as well, depending upon the magnitudes of offsetting income and substitution effects (cf. Butz and Ward, 1979; and Macunovich, 1995). The main effect is on the payoff to giving birth, but the influence on that payoff is unclear. During a recession, when the likelihood of employment is lower and those with jobs may have uncertain expectations regarding their stability, individuals' expected income is lower and they may choose to postpone childbearing (income effect). On the other hand, at precisely this time the opportunity cost of temporarily leaving the labor market to have a child is lower, increasing the value of giving birth at this time (substitution effect). The overall impact of economic conditions on births and, therefore, pregnancies and abortions as well, is theoretically indeterminate. 


\section{LITERATURE REVIEW}

This research is not the first to explore the impact of abortion and welfare policies and economic conditions on the outcomes considered here. The contributions of this work are that it examines each stage in the fertility decision tree simultaneously and it updates the literature to explore more recent policy changes. Nevertheless, it is useful to describe the findings of past work to compare to the results reported below.

\section{A. Abortion Policies}

Much of the research on the impact of abortion policy has been limited to its effect on the abortion rate. ${ }^{3}$ Its main focus was to show that the demand curve for abortions are downward sloping; restrictions reduce demand. Several papers have explored the impact of parental involvement laws on the abortion rate (cf. Cartoof and Klerman, 1988; Haas-Wilson, 1993 and 1996; Blank, et al. 1996; and Joyce and Kaestner, 1996). The evidence regarding the impact of these laws on the incidence of abortion is inconsistent across papers and model specifications.

The discrepancies may be attributable to several differences across papers. First, some of this research uses data on abortions by state of occurrence rather than state of residence (cf. Haas-Wilson, 1993 and 1996). Some teens respond to a parental involvement by obtaining an abortion in a neighboring state without such a law (cf. Cartoof and Klerman, 1988), indicating that estimates obtained from data by state of occurrence will overstate the impact of the law. Other research uses data for all women of childbearing age rather than just teens because they represent broader efforts

${ }^{3}$ This review regarding abortion policy concentrates on the impact of parental involvement and mandatory waiting period laws because those are the policies I will consider in the empirical analysis below. Past work has also explored the impact of Medicaid funding restrictions (cf. Trussell, 1980; Joyce, 1988; Lundberg and Plotnick, 1990 and 1995; Blank, et al., 1996, Levine, et al., 1996; Cook, et al., 1996; Currie, et al., 1996; Haas-Wilson, 1996; and Matthews, et al. 1996). 
to understand the determinants of abortion (cf. Blank, et al. 1996). These aggregated data make it more difficult to identify any impact of a parental involvement law that targets a small fraction of women. Still other work has employed a case study approach where one may anticipate a wide variety of estimates (cf. Cartoof and Klerman, 1988; Rogers, et al., 1991; and Joyce and Kaestner, 1997).

Some of the more recent research examining the impact of parental consent laws has examined births as an outcome as well, so that implications regarding pregnancies may be drawn. ${ }^{4}$ Among those studies that do find that these policies reduced abortions (Rogers, et al., 1991; Ohsfeldt and Gohmann, 1994; and some specifications in Matthews, et al., 1997), birthrates are estimated to either fall or remain constant, again indicating that pregnancies fell. In addition, Kane and Staiger (1996) find that parental involvement laws did not increase teen births and, if anything, reduced them. The results from these analyses suggest that these changes in abortion access may affect women's sexual activity and/or contraception behavior.

Given the relatively recent introduction of mandatory delay laws, less research has examined their impact. Preliminary evidence obtained very shortly after the implementation of such a law in Mississippi indicates that abortions declined after it went into effect (Althaus and Henshaw, 1994). Joyce, et al. (1997) show that a mandated waiting period reduced abortion rates in Mississippi relative to Georgia and South Carolina, but found no strong evidence of an increase in births.

${ }^{4}$ Argys, et al. (forthcoming) have also examined the impact of abortion policies on contraceptive use and sexual activity. Their use of a single cross-section of data, however, precludes the use of state fixed effects. 


\section{B. Welfare Policies}

A large literature has explored the relationship between the generosity of welfare benefits and fertility rates, which was recently reviewed by Moffitt (1998). Despite the clear theoretical prediction that more generous benefits should increase fertility, definitive empirical support for this position does not exist. Different studies using alternative methodologies and data sources have arrived at different answers. Moffitt summarizes these findings as follows: "A neutral weighing of the evidence still leads to the conclusion that welfare has incentive effects on marriage and fertility, but the uncertainty introduced by the disparities in the research findings weakens the strength of that conclusion."

Considerably less research has examined the impact of welfare benefit levels on the incidence of abortion; this work is reviewed in Klerman (1998). He reports that in a handful of studies that appropriately control for unobservable differences across states through the use of fixed effects (cf. Blank, et al., 1996; and Matthews, et al., 1997), welfare benefit levels have no significant effect on abortion rates.

Although welfare reform has only recently been enacted, a couple of studies have examined its impact on fertility (Horvath-Rose and Peters, 2000; and Kearney, 2001). These studies focus on one particular aspect of welfare reform, the family cap, and exclusively examine the impact on nonmarital fertility. Regarding the family cap, Horvath-Rose and Peters (2000) report that the family cap reduces fertility, but Kearney (2001) points out a number of methodological problems in their analysis. $^{5}$ In contrast, she finds either no effect or even a counterintuitive positive relationship

${ }^{5}$ For instance, Horvath-Rose and Peters do not account for the changes in the way marital status is measured in Vital Statistics data and they do not use codings of waivers that are consistent with the rest of the literature that has considered their impact (cf. Council of Economic Advisers, 
between the family cap and fertility in some specifications among those groups at high risk of welfare receipt. She concludes that there is no evidence of a negative impact of the family cap on fertility, viewing the counterintuitive findings as spurious. In this analysis, I will focus on the impact of the family cap as well as whether or not any welfare waivers had been enacted in a state and year. ${ }^{6}$

\section{Labor Market Conditions}

Past research has also examined the role of labor market conditions on fertility-related behavior. Recent evidence indicates that the birth rate is procyclical (cf. Jackson and Klerman, 1995; and Matthews, et al. 1997). Research examining the relationship between labor market conditions and the abortion rate is mixed. For instance, Matthews, et al. (1997) finds no relationship, but in some specifications Blank, et al. (1996) find that abortions increase as unemployment rises. Regarding sexual activity and contraceptive use, Levine (2001) has explored the impact of labor market conditions for school-age teens and finds that sexual activity is countercyclical, but finds no impact on contraceptive use.

\section{DATA}

This analysis will be conducted using three main sources of data on fertility-related outcomes. $^{7}$ Data on birth rates by state for all women were obtained for the 1985 to 1996 period from published sources available through the National Vital Statistics System. Data on births by age,

1997 and 1999).

${ }^{6}$ States that received waivers implemented a number of different types of provisions, but identifying the impact of each type of provision separately is quite difficult when one is relying upon cross-state variation. With only 51 (including DC) sets of potential experiments to consider, separately estimating the impact of several specific reform provisions along with other policy variables and economic conditions is not feasible.

${ }^{7}$ See the data appendix for a complete list of data sources. 
marital status, education and parity were computed by state for the same years using available Vital Statistics microdata. I also utilize abortion data by state of residence for all women and for teens by state that is available from the Alan Guttmacher Institute (AGI). Over the 1985 to 1996 period considered here, abortion data for all women is available for 1985, 1987, 1988, 1991, 1992, and 1996 and for teens is available for 1985, 1988, 1992, and 1996. Micro-level data on sexual activity and contraceptive use are obtained from Cycles 4 and 5 of the National Survey of Family Growth (NSFG), which were conducted in 1988 and 1995.

Each of these data sources has strengths and weaknesses for the purposes of this analysis. Regarding births, Vital Statistics data are ideal in the sense that these data represent a complete count, not a sample, are widely recognized as being very accurate, and are available in every year. These data do, however, possess a few important limitations. First, it is difficult to determine accurately the marital status of the mother in these data. Some states have inferred marital status on the basis of the last names of the mother and the father, an approach which will have introduced rising error rates over time. Moreover, some states have switched their methods for determining marital status, which could cause problems since some of these changes took place over the sample period considered here. Therefore, throughout this analysis of birth rates, in models that distinguish women by marital status I only use the set of states that consistently recorded marital status on the birth certificate throughout the sample period. ${ }^{8}$ Second, Vital Statistics data contains relatively few

${ }^{8}$ The states excluded because of this restriction include: California, Connecticut, Maryland, Michigan, Montana, Nevada, New York, Ohio, and Texas. In addition, the state of Washington (along with California, New York and Texas) does not include educational attainment of the mother on their birth certificate throughout the sample period, so it is excluded as well in models that distinguish women by this characteristic. 
other characteristics of mothers that could be used either to split the sample or to use as explanatory variables. Third, these data can only provide a count of births by state and year and require outside information on the size of the relevant population subgroup to determine birth rates. For overall birth rates and for births by age of mother, estimates available from the Census Bureau can be used to complete this task, but when mothers are separated by education or by parity among unmarried women, no such denominator exists.

Abortion data have different limitations. First, in surveys women are known to well underreport the occurrence of abortion (Jones and Forrest, 1992). Data available from the AGI is bestsuited to overcome this problem because it gathers information from abortion providers, including very small ones. This approach creates a second problem, however, in that data pertaining to particular states reflect the state in which the abortion provider is located and not the state in which the mother resides. Because women may respond to changes in abortion policy by obtaining abortions out of state, estimates of the impact of such changes based on data by state of occurrence may be misleading. In addition, because abortion providers supply the data, all that is obtained is a raw count of abortions, so it is impossible to distinguish the number of abortions performed for population subgroups.

Despite these limitations, AGI periodically reports estimates of the abortion rate by state of residence by integrating less complete abortion counts by the Centers for Disease Control (CDC). The CDC collects information from state public health agencies that includes information on the state in which abortions were performed and the woman's state of residence. Overall, the CDC data are widely regarded as inferior because they significantly undercount the number of abortions relative to AGI. But if the undercount is geographically uniform, the rates of migration can be used 
to adjust the more complete count conducted by AGI. This is the approach AGI adopts in their reports of the rate of abortions by state of residence; these are the data that are employed in this paper. ${ }^{9}$

In addition, AGI also reports abortion rates for women in different age groups by "state of residence." These data also incorporate information collected by the CDC on the age distribution of abortion recipients, but these data are collected by the state of occurrence rather than the state of residence. AGI still applies this information to the level of total abortions estimated by state of residence to provide estimates of the frequency of abortions among women in the 15 to 17,18 and 19 , and 20 to 44 age groups. This approach still leaves open the possibility of some bias if teens were more likely to migrate to obtain an abortion in response to changes in state abortion laws. ${ }^{10}$ In the empirical work described below, I follow the lead of Blank, et al. (1996) and control for border state abortion policies to help reduce this bias. Moreover, an additional advantage of examining each stage of the fertility decision tree is that it may help corroborate the evidence obtained from the AGI data.

The final source of data on fertility-related outcomes is the National Survey of Family Growth, cycles 4 and 5, containing data for 1988 and $1995 .^{11}$ These data provide the significant

${ }^{9}$ I have also estimated comparable models using the AGI data by state of occurrence and found results that are qualitatively similar to those reported below.

${ }^{10}$ In 1996, however, 29 states also reported special tabulations of state of residence by the age of abortion recipients that could be used to provide an indication of the extent of this bias in the count of teen abortions by state of residence. In a personal communication with Stanley Henshaw, who conducted this analysis for AGI, he indicated that the alternative approach did not make much of a difference.

${ }^{11}$ The respondents' state of residence, which is required to merge on the policy and economic conditions variables, are not available on public use versions of these data. Researchers can access 
benefit that they contain microdata on sexual activity, contraception, and a wide array of individual characteristics for samples of 8,450 and 10,830 women of childbearing age (15-44) in 1988 and 1995, respectively. These data have some disadvantages as well. First, the fact that the data are restricted to 1988 and 1995 means that much of the year-to-year variation in welfare benefit levels and in economic conditions is unavailable. At the state level, this reduces the sample available to 102 observations, and 51 possible changes, limiting the power of the analysis. Second, although sample sizes are large for the population as a whole, when these data are separated into population subgroups, the number of people in each group may get rather small. This is particularly true since the variation of interest comes at the state level and sufficient numbers of observations are required within each state cell for the particular subgroup to obtain precise estimates. For both of these reasons, statistical power is an important concern in the analysis using NSFG data. In addition, the behaviors considered here do not fully capture a woman's true risk of pregnancy. Sexual activity is characterized as a discrete measure, but its frequency is not considered here. Whether or not contraception was used at last intercourse misses the frequency of unprotected sex. Therefore, the behaviors measured here are only indicative of pregnancy risk and do not fully capture it.

\section{METHODOLOGY}

With each of these sources of data, I will use the cross-state and year variation that exists in each policy and in economic conditions to estimate difference-in-difference models of their impact on each of the relevant outcomes. Specifically, I will estimate regression models of each outcome on indicator variables for whether or not the particular policy was in place or, for the continuous

this information, however, by visiting the National Center for Health Statistics and conducting the analysis in their Research Data Center. As a result, I am not able to share the data used for this analysis with others. 
variables (welfare benefit levels and the unemployment rate), the variable itself along with state and year fixed effects. ${ }^{12}$

Where appropriate, the population will be divided into subgroups where a particular policy is targeted at one of the groups, but should have no impact on the other, as an additional means to help identify whether the estimated relationships are truly causal. For instance, I separate the sample by marital status and education level to identify groups more and less likely to be affected by changes in welfare policies among those who are likely to be eligible. ${ }^{13}$ Similarly, for less-skilled, unmarried women, I split the sample by parity to focus on the impact of the family cap. In addition, parental involvement laws should alter the behavior of minors, but not those over age 18 , so women over that age can be used like a control group..$^{14}$ In models where I split the sample by women's age, I follow Blank, et al. (1996) and also include a measure of border state abortion policies since abortion data by age does not completely correct for the fact that it is obtained by state of occurrence, not state of residence. The variables I include represent the fraction of border states to one's own state that have a parental involvement law or a mandatory delay law in effect. This fraction is calculated using

\footnotetext{
${ }^{12}$ For the welfare reform variables, I know precisely the day the policy was implemented, so in that year I code the variable as the fraction of the year it was in effect.

${ }^{13}$ It is important to keep in mind that marital status, in particular, may be endogenous, although prior research generally has not found large effects of social policy changes on marriage (c.f. Moffitt, 1998).

${ }^{14}$ Using the NSFG data I include women who are exactly age 18 at the survey date in the sample of minors because the activity addressed occurred within the past three months, when some of these women were minors, and because the impact on behavior, should it exist, may linger somewhat. I have also experimented with grouping just 15 to 17 year olds and obtained point estimates that were very similar to those reported below, but the smaller sample sizes led to greater imprecision in these estimates.
} 
weights representing the distance between the population centroid of the state and each of its neighbors.

In those models examining abortions and births, for which data are available for multiple years, I also test the sensitivity of the results to the inclusion of state-specific linear trends. In these models, I also control for aggregate demographic characteristics in each state and year, including the age and racial composition, the average educational attainment, and the fraction married among women between the ages of 15 and $44 .{ }^{15}$ The dependent variable in these models represents the log of the abortion and birth rates, so that coefficient estimates can be interpreted as percentage changes. I also create a "pregnancy rate," defined to be the sum of the abortion and birth rates, which captures the impact of the policies and economic conditions on pregnancies so long as the rate of spontaneous abortions are exogenous. In addition, in models that examine births by marital status, education, and parity, no denominator is available to create a birth rate, so the dependent variable represents the log of the number of births, as Kearney (2001) does. ${ }^{16}$ Because of the roughly 3 to 9 month lag between the time when a policy change occurs and the time when the impact could appear in abortions and births, all policy variables and the unemployment rate are entered with a one year lag. ${ }^{17}$

\footnotetext{
${ }^{15}$ These variables were estimated from merged outgoing rotation group data from the Current Population Survey.

${ }^{16}$ To examine the sensitivity of the results to this limitation, I used the universe of all women of childbearing age, for which both the number of births and the birth rate are available, and estimated identical models using the two different dependent variables (both in logs). The results from the two models were qualitatively similar.

${ }^{17}$ This also helps correct for the fact that some policies were only in effect for a portion of the year they were introduced, limiting their potential contemporaneous effect.
} 
In those models examining sexual activity and contraceptive use, the dependent variables represent indicator variables for whether or not the individual engaged in the particular behavior and estimates from linear probability models are reported. ${ }^{18}$ Sexual activity is measured as an indicator variable for whether or not the respondent has engaged in sexual intercourse in the past three months. Contraceptive use is measured as the failure to use contraception at last intercourse and these models are only estimated for the sample of women who have had sex in the past three months. I also generate an additional outcome, called "pregnancy risk," which represents an indicator variable for having engaged in sexual intercourse in the past three months without using contraception, thereby placing the individual at risk of pregnancy. In all of these models, I also control for an array of personal characteristics including marital status, age and age squared, number of children, race/ethnicity, education, rural residence, religion, mother's education, and whether or not the respondent's mother worked while the respondent was growing up. Because observations are only available for two years in each state, I cannot estimate these models controlling for state-specific trends. I enter those policy variables that are discrete with a one-year lag to make sure that the policy was actually in effect at the time the respondent reported her behavior.

As with any econometric exercise based on a quasi-experimental framework, one needs to be concerned about the exogeneity of the policy changes taking place. It is always a possibility that laws change in response to changes in behavior rather than the other way around. In this particular application, for those policies driven by Supreme Court decisions, this helps to lessen the problem since at least the exact timing of the policy change would be exogenous. Using comparison groups also is beneficial if the behavioral changes that may drive policy occur across groups. In addition,

\footnotetext{
${ }^{18}$ All standard errors are corrected for heteroskedasticity.
} 
in some instances the likely bias brought about by potential policy endogeneity may go in the opposite direction from that predicted by theory, as described earlier. For instance, if parental involvement laws are enacted in places with increasing teen abortion rates, this would introduce a spurious positive relationship between the laws and abortions when theory suggests the relationship should be negative. If the relationship is found to be negative, one could only argue that it should truly be bigger than what was estimated but the bias would not have driven the direction of the effect. Nevertheless, it is important to keep this caveat in mind.

\section{RESULTS}

\section{A. Descriptive Statistics}

Before discussing the results of the multivariate analysis, I first report sample means to provide some perspective on these data sources and the magnitude of subsequent results. Tables 2 and 3 provide these descriptive statistics for the aggregate data and for the NSFG, respectively. ${ }^{19}$ In Table 2, the sample is split into three sets of years depending upon data availability, as described previously. About 6.7 percent of women of childbearing age give birth in any given year; there is roughly 1 abortion for every 2.5 births. For younger and older teens, 3.4 and 8.5 percent give birth each year, respectively. One abortion is obtained for every 1.3 and 1.5 births for those 15 to 17 and those 18 and 19, respectively. This table also shows the extent to which women were exposed to the social policies considered here as well as the level of welfare benefits and the average unemployment they faced. Relatively few women lived in states and years with mandatory delay laws and a family cap policy, suggesting it may be difficult to capture their impact.

\footnotetext{
${ }^{19}$ In Table 2, I do not provide sample means for the log of the number of births by educational status and by parity to unmarried women because these statistics have little intuitive meaning.
} 
Table 3 describes the sexual activity and contraceptive use of women in different demographic groups. Among those women aged 15 to 18, over one-third were sexually active in the past 3 months and 21 percent of them did not use contraception at their last intercourse. Over half of unmarried women engaged in sexual activity in the past three months and 20 percent of them did not use contraception at their last intercourse. Similar percentages of women were exposed to the policy changes as found in the aggregate data, but the average unemployment rate is somewhat lower since 1988 and 1995 were both expansionary years. In fact, the failure to track the full business cycle may make it more difficult to identify the impact of unemployment on sexual activity and contraceptive use in these cycles of the NSFG.

\section{B. Aggregate Data}

Table 4 reports regression results using aggregate data on abortion rates, birth rates, and their sum, the "pregnancy rate" from models that either include or exclude state-specific linear trends. The results provide little evidence that abortion policy changes affect any of these outcomes for all women. Abortion rates show little response and the estimated impact on births and pregnancies is sensitive to the inclusion of state-specific trends. Welfare waivers are also found to have little systematic impact, although models with state-specific trends indicate a decline in births attributable to a decline in pregnancies. The family cap is found to increase births (as Kearney; 2001, found) and pregnancies, if it had any effect at all, contradicting predictions. More generous welfare benefits are estimated to increase the abortion rate, which contradicts the conventional wisdom, but is consistent with some models of behavior, as described earlier, and to increase birth rates, which indicate that such a rise increases the number of pregnancies as well. Finally, I find strong evidence 
that fertility is procyclical, and, in the model without state-specific trends, so are abortions. Regardless of specification, pregnancies are found to be procyclical as well.

Tables 5 through 7 split the aggregate data into samples of women aged 15 to 17,18 and 19 , and 20 to 44, respectively, to determine whether these policies and economic conditions affect these groups differently. This analysis is particularly useful for examining the impact of parental involvement laws, which should only affect the 15 to 17 year olds. Precision becomes more of an issue in these data, partly because of the smaller sample sizes of women in each cell (particularly for the teens) and partly because fewer years of data are available for abortions and, hence, pregnancies. This is particularly problematic in models attempting to control for state-specific linear trends because only four data points are available within each state to identify both policy impacts and the trend line itself.

Yet one strong finding emerges from these tables; parental involvement laws are found to reduce the abortion rate for teens regardless of the treatment of trends. The introduction of a parental involvement law is estimated to reduce the abortion rate of minors by 15 to 20 percent (Table 5). ${ }^{20}$ In the samples of older women (Tables 6 and 7), point estimates on the impact of these laws are about one-quarter to one-third of this size and are not statistically significant. ${ }^{21}$ Moreover, there is

${ }^{20} \mathrm{To}$ place the magnitude of this result in perspective it is useful to estimate the fraction of the decline in teen abortion rates over time that can be explained by parental involvement laws. Between 1985 and 1996, the abortion rate for women between the ages of 15 and 17 fell from 31 to 19 per 1,000 women (c.f. Henshaw and Van Vort, 1989; and Henshaw and Feivelson, 2000). Over this period, the percentage of teens covered by parental involvement laws increased from 20 percent to 49 percent. If these laws reduced the abortion rate among women in this age group by 15 to 20 percent, then they could explain a reduction in the abortion rate on the order of 4.4 to 5.8 percentage points, which represents 37 to 48 percent of the overall decline.

${ }^{21}$ In models without state-specific trends, the coefficients on parental involvement for teens and non-teens are significantly different from each other. In models with state-specific trends they 
no evidence that births to minors rise in response, indicating that teen pregnancies must have declined. This is what the final two columns of Table 5 reports, although the estimated decline in models with state-specific trends is not statistically significant. Other findings in these tables are inconsistent across model specifications and age groups. It is important to note that the specifications in these three tables include the border state abortion policy variables described earlier, lessening the likelihood that these results are driven by cross-state migration in response to changes in parental consent laws. It turns out that these border state variables are largely statistically insignificant in these specifications.

Table 8 reports the impact of these policies and economic conditions on the log of the number of births by educational category and marital status. Since welfare eligibility strongly favors unmarried women, particularly over the sample period considered here, one would expect welfare policies to have a larger effect on unmarried women with less-education. The evidence in this regard is mixed. Among unmarried women in models without state-specific trends, log births are positively related to welfare benefit levels for less educated women (high school dropouts and high school graduates), but not more educated women. However, this pattern is not robust to the inclusion of state-specific trends. In addition, coefficients for less-educated married women are not significantly different than coefficients for less-educated unmarried women. The pattern of results regarding

are not significantly different from each other, perhaps because of the difficulty of identifying all of the models' parameters as well state-specific trends with only four observations per state. Moreover, it is not clear that parental involvement laws, as coded here, should have no impact on adult abortion rates. At least some state laws that included parental involvement provisions also included other provisions that would have affected adults that I have not controlled for here. For instance, the Pennsylvania law that led to the Casey decision also included a provision requiring that all women be provided with information about fetal development and the abortion procedure itself, which may have had differential impacts on adults and teens. 
welfare waivers and family cap policies among less-skilled women or across groups distinguished by marital status and educational attainment generally do not support the hypothesis that these policies reduce fertility.

To examine the impact of family cap policies more specifically, Table 9 presents results from models estimated only among unmarried women without a high school degree, splitting the sample between first births and higher order births. The family cap policy should have a larger impact on higher order births. ${ }^{22}$ The results reported here do not provide any evidence that family caps have the predicted effect. Point estimates on the family cap variable in models using higher order births only are about zero. Although these estimates are lower than the estimated positive impact on first births, which is likely to be spurious, they are not significantly different between the two groups.

\section{NSFG Data}

The results from estimates of models of sexual activity and contraceptive use from the NSFG are reported in Tables 9 through 11. Each table considers a different outcome; unprotected sexual activity in Table 9, and its inputs, sexual activity in the past three months and failure to use contraception at last intercourse in Tables 10 and 11, respectively. Models are estimated for all women as well as for a variety of population subgroups, all of which are unmarried to focus on those women most likely to be affected by these policies.

The results displayed in these tables are generally weak, with little systematic pattern in the coefficients, which are typically insignificant. As noted earlier, the lack of power in these data is

${ }^{22} \mathrm{~A}$ family cap could reduce the number of first births as well in a dynamic model where a woman's decision to have a first birth is made within an optimal program of lifecycle fertility. To the extent that this behavior occurs, however, we would still expect the impact on first births to be smaller than that on higher order births if only because some women do not plan to have more than one child. 
certainly a potential contributor to this. There are some exceptions, however, that do support some of the earlier findings.

One set of results is particularly noteworthy. The introduction of parental involvement laws is found to lead to a 6 percentage point reduction (with a p-value of 8 percent) in unprotected sexual activity for women between the ages of 15 and $18 .^{23}$ This effect is largely attributable to the greater reliance on contraception among teens in the presence of a parental involvement law. ${ }^{24}$ The introduction of such a law is found to increase the use of contraception at last intercourse by 16.5 percent (with a p-value of 6 percent). The p-values on a test of significance of these estimates compared to those for women aged 19 to 24 and women aged 25 to 44 are all in the vicinity of 6 percent. These point estimates are quite large considering that, according to these data, only about 8.4 percent of minors engage in unprotected sexual activity and 25.3 percent of sexually active teens failed to use contraception at last intercourse as reported in Table 3 (although these levels rose from 7 percent and 21 percent in 1988 to almost 10 percent and 30 percent, respectively, in 1995). They are not very precisely estimated, however. These results support the findings from aggregate data that parental involvement laws reduced pregnancies for minors but not for older women through their impact on contraceptive use.

${ }^{23}$ Levine (2001) also estimated the impact of parental notification laws on sexual activity and contraceptive use using data from the YRBS over the 1991 to 1997 period, but found little impact. A potential explanation for this discrepancy is that the YRBS only samples a subset of the states and over that sample period only 5 states (Iowa, Maryland, Mississippi, North Carolina, and Pennsylvania) instituted a parental involvement law and had data both before and after the law change.

${ }^{24}$ I have attempted to determine the form of contraception that drives this result, focusing on condoms and birth control pills, but sample size limitations led to estimates that were too imprecise to learn much at this finer level of detail. 
Elsewhere, earlier findings indicated that fertility and pregnancies are procyclical. Evidence from the NSFG supports this for unmarried women, who are found to be less likely to engage in unprotected sexual activity when the economy is weak; this response is attributable to their greater propensity to use contraception rather than a change in sexual activity. ${ }^{25}$ Welfare benefit levels are also found to be positively correlated with sexual activity, which is consistent with the positive estimated relationship with fertility described earlier. This effect is somewhat bigger among women with less education, but the difference is not significant. Moreover, I do not find the broader measure of unprotected sexual activity to be significantly related to welfare generosity for any group. Consistent with earlier findings, there is no evidence here of any impact of the family cap or welfare waivers more generally.

\section{DISCUSSION}

This paper has explored the impact of relatively recent changes in abortion and welfare policy along with economic conditions on behavior throughout the fertility decision tree. An important contribution of this paper is the attempt to determine whether inferential effects on the likelihood of pregnancy can be supported by direct estimates on the behaviors that would lead to a pregnancy. This approach was successful regarding the impact of parental involvement laws and, to some extent, for economic conditions. Using aggregate data from the Vital Statistics system and the Alan Guttmacher Institute, I found that parental involvement laws reduced abortion rates for younger teens, but not for older teens or adult women. These laws are not found to have increased births, however, providing the inference that pregnancies must have declined. Results obtained from an

${ }^{25}$ Levine (2001) finds evidence that teen girls reduce their sexual activity and use contraception more frequently when the labor market is weak. That analysis used biannual data over the 1991 through 1997 period from the Youth Risk Behavior Survey (YRBS). 
analysis of the 1988 and 1995 NSFG support this position. Parental involvement laws are found to reduce the risk of pregnancy through increased use of contraception for minors, but not older groups of women. In addition, results from aggregate data indicate that pregnancies and births are procyclical; this result was supported in the NSFG in that unprotected sexual activity is procyclical as well, brought about by changes in contraceptive use, among unmarried women.

Regarding welfare policy, I found mixed evidence regarding the relationship between benefit levels and fertility. Results indicated that more generous benefits are associated with increases in births, as well as abortions and pregnancies. When the population is broken down by education and marital status, however, the pattern of results does not strongly support a causal interpretation of this finding. Evidence from NSFG data on sexual activity and contraceptive use indicates that these data proved too weak to provide much supportive evidence in this regard. Perhaps one of the more important findings of this study is that little evidence supports the notion that welfare waivers as a whole or the family cap in particular had much of an impact on fertility-related behavior. This failure to find any effect of these policies appears at each stage of the fertility decision tree. 


\section{REFERENCES}

Argys, Laura M., Susan L. Averett, and Daniel I. Rees. “The Impact of Government Policies and Neighborhood Characteristics on Teenage Sexual Activity and Contraceptive Use." American Journal of Public Health. forthcoming.

Becker, Gary S. A Treatise on the Family. Cambridge, MA: Harvard University Press, 1981.

Blank, Rebecca, Christine George, and Rebecca London, "State Abortion Rates: The Impact of Policies, Providers, Politics, Demographics, and Economic Environment," Journal of Health Economics, 15(5), October 1996, 513-553.

Butz, William P. and Michael P. Ward. "The Emergence of Countercyclical U.S. Fertility." American Economic Review. Vol. 69, No. 3 (June 1979). pp. 318-328.

Cartoof, V. G. and L.V. Klerman. "Parental Consent for Abortion: Impact of the Massachusetts Law." American Journal of Public Health. April 1986. pp. 397-400.

Cook, Philip J., Allan M. Parnell, Michael J. Moore, and Deanna Pagnini. "The Effects of ShortTerm variation in Abortion Funding on Pregnancy Outcomes." National Bureau of Economic Research Working Paper, No. 5843, November 1996.

Council of Economic Advisers. "Technical Report: Explaining the Decline in Welfare Receipt, 1993-1996." Washington, DC: Council of Economic Advisers, May 1997. Mimeo.

Council of Economic Advisers. "Technical Report: The Effects of Welfare Policy and the Economic Expansion on Welfare Caseloads: An Update." Washington, DC: Council of Economic Advisers, August 1999. Mimeo.

Crouse, Gil. State Implementation of Major Changes to Welfare Policies, 1992-1998. unpublished manuscript, Office of Human Services Policy, Assistant Secretary for Planning and Evaluation, U.S. Department of Health and Human Services. 1999.

Currie, Janet, Lucia Nixon, and Nancy Cole, "Restrictions on Medicaid Funding of Abortion: Effects on Pregnancy Resolutions and Birth Weight," Journal of Human Resources, 31(1), Winter 1996, 159-188.

Haas-Wilson, Deborah. "The Economic Impact of State Restrictions on Abortion: Parental Consent and Notification Laws and Medicaid Funding Restrictions." Journal of Policy Analysis and Management. Vol. 12, No. 3 (Summer 1993). pp. 498-511. 
Haas-Wilson, Deborah. "The Impact of State Abortion Restrictions on Minor's Demand for Abortions." Journal of Human Resources. Vol. 31, No. 1 (Winter 1996). pp. 140-158.

Horvath-Rose, Anne and H. Elizabeth Peters. "Welfare Waivers and Nonmarital Childbearing." Joint Center for Poverty Research working paper 128. January 2000.

Jackson, Catherine A. and Jacob Alex Klerman. "Welfare and American Fertility." Unpublished manuscript, Rand Corporation. July 1995.

Jones, Elise F. and Jacqueline Darroch Forrest, 1992, Underreporting of Abortion in Surveys of U.S. Women: 1976 to 1988, Demography, Vol. 29, No. 1 (February 1992). pp. 113-126.

Joyce, Theodore, "The Social and Economic Correlates of Pregnancy Resolution Among Adolescents in New York City, by Race and Ethnicity: A Multivariate Analysis," American Journal of Public Health, Vol. 78 (1988). pp. 626-631.

Joyce, Theodore and Robert Kaestner. "State Reproductive Policies and Adolescent Pregnancy Resolution: The Case of Parental Involvement Laws." Journal of Health Economics, Vol. 15 (1996).

Joyce, Theodore, Stanley Henshaw, and Julia DeClerque Skatrud. "The Impact of Mississippi's Mandatory Delay Law on Abortions and Births." Journal of the American Medical Association. Vol. 278, No. 8 (August 27, 1997). pp. 653-658.

Kane, Thomas and Douglas Staiger, "Teen Motherhood and Abortion Access," Quarterly Journal of Economics, 111(2), May 1996, 467-506.

Kearney, Melissa Schettini. "Is There an Effect of Incremental Welfare Benefits on Fertility Behavior? A Look at the Family Cap." MIT Department of Economics, unpublished manuscript. July 2001.

Klerman, Jacob Alex. "Welfare Reform and Abortion," in Robert A. Moffit (ed.), Welfare, the Family, and Reproductive Behavior: Research Perspectives. Washington, DC: National Academy Press, 1998.

Levine, Phillip B. "The Sexual Activity and Birth Control Use of American Teenagers," in Jonathan Gruber (ed.), An Economic Analysis of Risky Behavior among Youths. Chicago: University of Chicago Press, 2001.

Levine, Phillip B. and Douglas Staiger. "Abortion as Insurance." National Bureau of Economic Research, working paper 8813, March 2002. 
Levine, Phillip B, Amy Trainor, and David J. Zimmerman. "The Effect of State Medicaid Funding Restrictions on Pregnancy, Abortion, and Births," Journal of Health Economics, Volume 15 (1996), pp. 555-578.

Levine, Phillip B. and Diane M. Whitmore. "The Impact of Welfare Reform on the AFDC Caseload." pp. 24-33 in National Tax Association Proceedings - 1997. Washington, DC: National Tax Association, 1998.

Lundberg, Shelly and Robert D. Plotnick. "Effects of State Welfare, Abortion, and Family Planning Policies on Premarital Childbearing Among White Adolescents." Family Planning Perspectives. Vol. 22, No. 6 (November/December 1990), pp. 246-251.

Lundberg, Shelly and Robert D. Plotnick, "Adolescent Premarital Childbearing: Do Economic Incentives Matter," Journal of Labor Economics, 13(2), April 1995, 177-200.

Macunovich, Diane J. "The Butz-Ward Model in the Light of More Recent Data." Journal of Human Resources. Vol. 30, No. 2 (Spring 1995). pp. 229-255.

Matthews, Stephen, David Ribar, and Mark Wilhelm, "The Effects of Economic Conditions and Access to Reproductive Health Services on State Abortion and Birthrates." Family Planning Perspectives. Vol. 29, No. 2 (March/April 1997). pp. 52-60.

Moffitt, Robert A. "The Effect of Welfare on Marriage and the Family," in Robert A. Moffit (ed.), Welfare, the Family, and Reproductive Behavior: Research Perspectives. Washington, DC: National Academy Press, 1998.

Ohsfeldt, Robert L. and Stephan F. Gohmann. "Do Parental Involvement Laws Reduce Adolescent Abortion Rates?" Contemporary Economic Policy. Vol. 12 (1994), pp. 65-76.

Rogers, James L., Robert F. Boruch, George B. Stoms, and Dorothy DeMoya. "Impact of the Minnesota Parental Notification Law on Abortion and Birth." American Journal of Public Health. Vol. 81, No. 3 (March 1991). pp. 294-298.

Trussell, James T., Jane Menken, Barbara L. Lindheim, and Barbara Vaugh. "The Impact of Restricting Medicaid Funding for Abortion.” Family Planning Perspectives. Vol. 12, no. 3 (1980), pp. 120-130. 


\section{DATA APPENDIX}

Sources for State Policies and Economic Conditions:

Alan Guttmacher Institute. State Reproductive Health Monitor. New York: Alan Guttmacher Institute. Various issues.

Althaus, Frances A. and Stanley K. Henshaw. "The Effects of Mandatory Delay Laws on Abortion Patients and Providers." Family Planning Perspectives. Vol. 26, No. 5 (September/October 1994). pp. 228-233.

Council of Economic Advisers. "The Effects of Welfare Policy and the Economic Expansion on Welfare Caseloads: An Update." Unpublished manuscript, Council of Economic Advisers, August 3,1999 .

Crouse, Gil. State Implementation of Major Changes to Welfare Policies, 1992-1998. unpublished manuscript, Office of Human Services Policy, Assistant Secretary for Planning and Evaluation, U.S. Department of Health and Human Services. 1999.

National Abortion and Reproductive Rights Action League. A State-by-State Review of Abortion and Reproductive Rights." Washington, DC: the NARAL Foundation. Various issues

Sollom, Terry. "State Legislation on Reproductive Health Issues in 1992: What was Proposed and Enacted. Family Planning Perspectives. Vol. 25, No. 2 (March/April 1993). Pp. 87-90.

Sollom, Terry. "State Actions on Reproductive Health Issues in 1994." Family Planning Perspectives. Vol. 27, No. 2 (March/April 1995). pp. 83-87.

Sollom, Terry. "State Actions on Reproductive Health Issues in 1996." Family Planning Perspectives. Vol. 29, No. 1 (January/February 1997). pp. 35-40.

Sources for Teenage Abortion, Birth, and Pregnancy Statistics:

Henshaw, Stanley K. and Jennifer Van Vort. "Teenage Abortion, Birth and Pregnancy Statistics: An Update. Family Planning Perspectives. Vol. 21, No. 2 (March/April 1989). pp. 85-88.

Henshaw, Stanley K. "Teenage Abortion, Birth and Pregnancy Statistics by State, 1988. Family Planning Perspectives. Vol. 25, No. 3 (May/June 1993). pp. 122-126.

Henshaw, Stanley K. "Teenage Abortion and Pregnancy Statistics by State, 1992. Family Planning Perspectives. Vol. 29, No. 3 (May/June 1997). pp. 115-122.

Henshaw, Stanley K. and Dina J. Feivelson. "Teenage Abortion and Pregnancy Statistics by State, 1996. Family Planning Perspectives. Vol. 32, No. 6 (November/December 2000). pp. 272-280. 
Sources for Population Abortion, Birth, and Pregnancy Statistics:

Henshaw, Stanley K. "Abortion Incidence and Services in the United States, 1995-1996." Family Planning Perspectives, Vol. 30, No. 6 (November/December, 1998). pp. 263-270, and 287.

Henshaw, Stanley K. and Jennifer Van Vort. "Abortion Services in the United States, 1991-1992." Family Planning Perspectives, Vol. 26, No. 3 (May/June, 1994). pp. 100-106 and 112.

Henshaw, Stanley K. and Jennifer Van Vort. "Abortion Services in the United States, 1987-1988." Family Planning Perspectives, Vol. 22, No. 3 (May/June, 1990). pp. 102-108 and 142.

Henshaw, Stanley K. and Jennifer Van Vort. “Abortion Services in the United States, 1984-1985." Family Planning Perspectives, Vol. 19, No. 2 (March/April, 1987). pp. 63-70.

U.S. Bureau of the Census. Vital Statistics of the United States. Washington, DC: U.S. Government Printing Office. annual editions.

Sources for Explanatory Variables:

Author's calculations from the National Bureau of Economic Research, Merged Outgoing Rotation Group file from the Current Population Survey.

U.S. Bureau of the Census, Population Estimates Branch. "Population Estimates for the U.S., Regions, Divisions, and States by 5-year Age Groups and Sex: Time Series Estimates, July 1, 1990 to July 1, 1999 and April 1, 1990 Census Population Counts." Online. http://www.census.gov/population/estimates/state/st-99-08.txt, July 23, 2001.

U.S. Bureau of the Census, Population Estimates Branch. "Resident Population of States (by 5-Year Age Groups and Sex)." Online. http://www.census.gov/population/estimates/state/s5yr8090.txt, July 23, 2001. 
Table 1: Abortion and Welfare Policy Changes at the State Level between 1985 and 1995

(Year of Change in Parentheses)

\begin{tabular}{|c|c|c|c|}
\hline Welfare Waivers & Family Cap & Parental Involvement & Mandatory Delay \\
\hline Arizona (1995) & Arizona (1995) & Alabama (1987) & Idaho (1995) \\
\hline Arkansas (1994) & Arkansas (1994) & Arkansas (1989) & Kansas (1992) \\
\hline California (1992) & Georgia (1994) & Connecticut (1990) & Louisiana (1995) \\
\hline Delaware (1995) & Illinois (1995) & Delaware (1995) & Mississippi (1992) \\
\hline Georgia (1994) & Indiana (1995) & Georgia (1991) & Nebraska (1993) \\
\hline Illinois (1993) & Massachusetts & Kansas (1992) & North Dakota (1994) \\
\hline Indiana (1995) & (1995) & Kentucky (1994) & Ohio (1994) \\
\hline Iowa $(1993)$ & Mississippi (1995) & Maine (1989) & Pennsylvania (1994) \\
\hline Massachusetts (1995) & Nebraska (1995) & Maryland (1992) & South Carolina (1995) \\
\hline Michigan (1992) & New Jersey (1992) & Michigan (1991) & South Dakota (1994) \\
\hline Mississippi (1993) & Virginia (1995) & Minnesota (1990) & Utah (1994) \\
\hline Missouri (1995) & & Mississippi (1993) & \\
\hline Nebraska (1995) & & Nebraska (1991) & \\
\hline New Jersey (1992) & & North Carolina (1995) & \\
\hline Oregon (1993) & & Ohio (1985) & \\
\hline South Dakota (1994) & & Pennsylvania (1994) & \\
\hline Utah (1993) & & South Carolina (1990) & \\
\hline Vermont (1994) & & Tennessee $(1995)$ & \\
\hline \multirow[t]{2}{*}{ Virginia (1995) } & & Utah (1985) & \\
\hline & & Wyoming (1989) & \\
\hline
\end{tabular}

\section{Notes:}

Crouse (1999) presents exact dates of implementation for welfare policy changes. In the analysis reported here, I use the fraction of the year each welfare policy was in effect. All welfare policy changes occurring in 1995 and earlier represent waivers from existing federal regulations. Some changes in 1996 represent waivers while others reflect the early implementation of TANF. Other states had implemented parental involvement laws prior to 1985 and are not listed because the change did not occur during the period under consideration here. Minnesota's parental involvement law was reinstituted in 1990 after 3 years in which judicial action prevented its enforcement.

Sources (see Data Appendix):

Parental Involvement Laws:

1985 through 1990: Blank, et al. (1996)

1991 through 1996: Sollom (1993, 1995, and 1997), Alan Guttmacher Institute (various years) and National Abortion and Reproductive Rights Action

League (various years).

Mandatory Delay Laws: Althaus and Henshaw (1994), Sollom (1995 and 1997) and National Abortion Rights Action League (various years).

Welfare Policies: Crouse (1999). 


\begin{tabular}{|c|c|c|c|}
\hline Variable & All Years & AGI Years & AGI Teen Years \\
\hline \multicolumn{4}{|l|}{ Birth Rate (births per 1,000 women aged 15 to 44 ) } \\
\hline All Women, 15 to 44 & 67.4 & 67.2 & \\
\hline Age 15 to 17 & & & 33.9 \\
\hline Age 18 and 19 & & & 85.3 \\
\hline Non-Teens & & & 69.1 \\
\hline \multicolumn{4}{|l|}{ Abortion Rate (abortions per 1,000 women aged 15 to 44 ) } \\
\hline All Women, 15 to 44 & & 26.3 & \\
\hline Age 15 to 17 & & & 25.8 \\
\hline Age 18 and 19 & & & 56.4 \\
\hline Non-Teens & & & 23.8 \\
\hline \multicolumn{4}{|l|}{ "Pregnancy Rate" (abortion rate plus birth rate) } \\
\hline All Women, 15 to 44 & & 93.5 & \\
\hline Age 15 to 17 & & & 59.7 \\
\hline Age 18 and 19 & & & 141.7 \\
\hline Non-Teens & & & 93.1 \\
\hline \multicolumn{4}{|l|}{ Percentage of Women in States/Years with: } \\
\hline Parental Involvement Law & 29.8 & 28.4 & 30.1 \\
\hline Mandatory Delay Law & 4.2 & 3.1 & 4.6 \\
\hline Reformed Welfare System & 12.9 & 11.1 & 16.7 \\
\hline Family Cap & 4.2 & 4.9 & 7.4 \\
\hline Max. Monthly Welfare Benefits, Family of 3, 1996 dollars & 468 & 474 & 465 \\
\hline Female Unemployment Rate & 6.2 & 6.4 & 6.4 \\
\hline Sample Size (States/Years) & 612 & 306 & 204 \\
\hline
\end{tabular}

Notes: All estimates are weighted by the number of women in each state/year of the relevant age group. AGI years include 1985, 1987, 1988, 1991, 1992, and 1996. AGI teen years include 1985, 1999, 1992, and 1996. 
Table 3: Sample Means of NSFG Data

Unmarried Women

\begin{tabular}{|c|c|c|c|c|c|c|c|c|c|}
\hline & \multirow[b]{3}{*}{$\begin{array}{c}\text { All } \\
\text { Women } \\
\end{array}$} & \multirow[b]{3}{*}{$\begin{array}{l}\text { Unmarried } \\
\text { Women }\end{array}$} & \\
\hline & & & & & & & & \multicolumn{2}{|c|}{$\leq$ HS Degree } \\
\hline & & & $\begin{array}{c}\text { Age } \\
15-18\end{array}$ & $\begin{array}{l}\text { Age } \\
19-24\end{array}$ & $\begin{array}{c}\text { Age } \\
25-44\end{array}$ & $\begin{array}{c}\leq \mathrm{HS} \\
\text { Degree }\end{array}$ & $\begin{array}{l}\geq \text { Some } \\
\text { College }\end{array}$ & $\begin{array}{c}\text { no } \\
\text { children }\end{array}$ & $\geq 1$ child \\
\hline Percent Engaging in Sexual Activity, Past 3 Months & 77.7 & 57.3 & 33.0 & 66.3 & 64.1 & 56.7 & 58.2 & 42.8 & 77.9 \\
\hline Percent Sexually Active, No Contraception at Last Intercourse & 23.2 & 21.3 & 25.3 & 20.9 & 20.6 & 26.0 & 14.3 & 26.8 & 25.4 \\
\hline Percent "At-Risk of Pregnancy" & 18.0 & 12.2 & 8.4 & 13.9 & 13.2 & 14.7 & 8.3 & 11.5 & 19.8 \\
\hline \multicolumn{10}{|l|}{ Percent Subject to: } \\
\hline Parental Involvement Law & 33.7 & 34.2 & 34.4 & 36.5 & 32.7 & 35.1 & 32.7 & 34.8 & 35.4 \\
\hline Mandatory Delay Law & 8.2 & 8.2 & 8.8 & 8.6 & 7.7 & 9.0 & 7.1 & 8.7 & 9.4 \\
\hline Reformed Welfare System & 18.4 & 18.5 & 18.1 & 17.3 & 19.2 & 18.0 & 19.2 & 16.4 & 20.3 \\
\hline Family Cap & 5.5 & 5.5 & 5.2 & 5.1 & 5.8 & 5.5 & 5.4 & 4.9 & 6.5 \\
\hline Max.Welfare Benefits, Family of 3, 1996 dollars & 458 & 459 & 450 & 464 & 461 & 448 & 478 & 455 & 437 \\
\hline Female Unemployment Rate & 5.7 & 5.7 & 5.8 & 5.6 & 5.7 & 5.7 & 5.6 & 5.7 & 5.8 \\
\hline Sample Size & 19,222 & 9,935 & 2,062 & 2,556 & 5,337 & 6,297 & 3,638 & 3,179 & 3,118 \\
\hline
\end{tabular}

Notes: Estimates are weighted to provide statistics that are nationally representative. 
Table 4: Impact of Changes in Abortion and Welfare Policies and Economic Conditions

on Abortion, Birth, and Pregnancy Rates - All Women Age 15-44 (robust standard errors reported in parentheses)

\begin{tabular}{|c|c|c|c|c|c|c|c|c|}
\hline \multirow[b]{2}{*}{ Parental Involvement } & \multicolumn{2}{|c|}{ Abortion Rate } & \multicolumn{2}{|c|}{ Birth Rate - AGI Years } & \multicolumn{2}{|c|}{ Birth Rate - All Years } & \multicolumn{2}{|c|}{ Pregnancy Rate } \\
\hline & $\begin{array}{l}-0.022 \\
(0.021)\end{array}$ & $\begin{array}{l}-0.004 \\
(0.022)\end{array}$ & $\begin{array}{l}-0.010 \\
(0.007)\end{array}$ & $\begin{array}{l}-0.002 \\
(0.005)\end{array}$ & $\begin{array}{l}-0.017 \\
(0.005)\end{array}$ & $\begin{array}{l}-0.002 \\
(0.004)\end{array}$ & $\begin{array}{l}-0.014 \\
(0.007)\end{array}$ & $\begin{array}{l}-0.003 \\
(0.006)\end{array}$ \\
\hline Mandatory Delay & $\begin{array}{c}0.007 \\
(0.032)\end{array}$ & $\begin{array}{c}0.044 \\
(0.044)\end{array}$ & $\begin{array}{l}-0.044 \\
(0.011)\end{array}$ & $\begin{array}{l}-0.027 \\
(0.009)\end{array}$ & $\begin{array}{l}-0.017 \\
(0.007)\end{array}$ & $\begin{array}{l}-0.005 \\
(0.005)\end{array}$ & $\begin{array}{l}-0.026 \\
(0.010)\end{array}$ & $\begin{array}{l}-0.009 \\
(0.014)\end{array}$ \\
\hline $\begin{array}{l}\text { Welfare Waiver } \\
\text { Implemented }\end{array}$ & $\begin{array}{l}-0.052 \\
(0.046)\end{array}$ & $\begin{array}{c}0.002 \\
(0.038)\end{array}$ & $\begin{array}{l}-0.004 \\
(0.008)\end{array}$ & $\begin{array}{l}-0.057 \\
(0.012)\end{array}$ & $\begin{array}{c}0.008 \\
(0.007)\end{array}$ & $\begin{array}{l}-0.031 \\
(0.007)\end{array}$ & $\begin{array}{l}-0.024 \\
(0.019)\end{array}$ & $\begin{array}{l}-0.038 \\
(0.015)\end{array}$ \\
\hline Family Cap & $\begin{array}{c}0.105 \\
(0.069)\end{array}$ & $\begin{array}{l}-0.001 \\
(0.062)\end{array}$ & $\begin{array}{c}0.029 \\
(0.022)\end{array}$ & $\begin{array}{c}0.080 \\
(0.017)\end{array}$ & $\begin{array}{c}0.025 \\
(0.014)\end{array}$ & $\begin{array}{c}0.053 \\
(0.010)\end{array}$ & $\begin{array}{c}0.058 \\
(0.032)\end{array}$ & $\begin{array}{c}0.071 \\
(0.024)\end{array}$ \\
\hline $\begin{array}{l}\text { log Maximum } \\
\text { Welfare Benefits }\end{array}$ & $\begin{array}{c}0.356 \\
(0.129)\end{array}$ & $\begin{array}{c}0.264 \\
(0.132)\end{array}$ & $\begin{array}{c}0.116 \\
(0.037)\end{array}$ & $\begin{array}{c}0.053 \\
(0.027)\end{array}$ & $\begin{array}{c}0.132 \\
(0.025)\end{array}$ & $\begin{array}{c}0.068 \\
(0.020)\end{array}$ & $\begin{array}{c}0.197 \\
(0.049)\end{array}$ & $\begin{array}{c}0.126 \\
(0.042)\end{array}$ \\
\hline $\begin{array}{l}\text { Female } \\
\text { Unemployment Rate }\end{array}$ & $\begin{array}{l}-0.012 \\
(0.005)\end{array}$ & $\begin{array}{l}-0.003 \\
(0.006)\end{array}$ & $\begin{array}{c}-0.07 \\
(0.002)\end{array}$ & $\begin{array}{l}-0.007 \\
(0.001)\end{array}$ & $\begin{array}{l}-0.007 \\
(0.001)\end{array}$ & $\begin{array}{l}-0.007 \\
(0.001)\end{array}$ & $\begin{array}{l}-0.009 \\
(0.002)\end{array}$ & $\begin{array}{l}-0.006 \\
(0.002)\end{array}$ \\
\hline State Trends & No & Yes & No & Yes & No & Yes & No & Yes \\
\hline
\end{tabular}


Table 5: Impact of Changes in Abortion and Welfare Policies and Economic Conditions on Abortion, Birth, and Pregnancy Rates - Women Age 15-17 (robust standard errors reported in parentheses)

\begin{tabular}{|c|c|c|c|c|c|c|c|c|}
\hline \multirow[b]{2}{*}{ Parental Involvement } & \multicolumn{2}{|c|}{ Abortion Rate } & \multicolumn{2}{|c|}{ Birth Rate - AGI Years } & \multicolumn{2}{|c|}{ Birth Rate - All Years } & \multicolumn{2}{|c|}{ Pregnancy Rate } \\
\hline & $\begin{array}{l}-0.215 \\
(0.040)\end{array}$ & $\begin{array}{l}-0.147 \\
(0.074)\end{array}$ & $\begin{array}{l}-0.026 \\
(0.018)\end{array}$ & $\begin{array}{c}0.029 \\
(0.018)\end{array}$ & $\begin{array}{l}-0.020 \\
(0.009)\end{array}$ & $\begin{array}{c}0.013 \\
(0.009)\end{array}$ & $\begin{array}{l}-0.091 \\
(0.019)\end{array}$ & $\begin{array}{l}-0.039 \\
(0.028)\end{array}$ \\
\hline Mandatory Delay & $\begin{array}{c}0.016 \\
(0.064)\end{array}$ & $\begin{array}{c}0.071 \\
(0.125)\end{array}$ & $\begin{array}{l}-0.040 \\
(0.022)\end{array}$ & $\begin{array}{l}-0.043 \\
(0.035)\end{array}$ & $\begin{array}{l}-0.025 \\
(0.012)\end{array}$ & $\begin{array}{c}0.001 \\
(0.010)\end{array}$ & $\begin{array}{l}-0.015 \\
(0.028)\end{array}$ & $\begin{array}{l}-0.015 \\
(0.044)\end{array}$ \\
\hline $\begin{array}{l}\text { Welfare Waiver } \\
\text { Implemented }\end{array}$ & $\begin{array}{l}-0.004 \\
(0.095)\end{array}$ & $\begin{array}{c}0.055 \\
(0.168)\end{array}$ & $\begin{array}{c}0.000 \\
(0.036)\end{array}$ & $\begin{array}{l}-0.067 \\
(0.043)\end{array}$ & $\begin{array}{c}0.012 \\
(0.016)\end{array}$ & $\begin{array}{l}-0.066 \\
(0.015)\end{array}$ & $\begin{array}{l}-0.037 \\
(0.043)\end{array}$ & $\begin{array}{l}-0.004 \\
(0.067)\end{array}$ \\
\hline Family Cap & $\begin{array}{c}0.031 \\
(0.113)\end{array}$ & $\begin{array}{c}0.003 \\
(0.220)\end{array}$ & $\begin{array}{l}-0.007 \\
(0.050)\end{array}$ & $\begin{array}{c}0.144 \\
(0.060)\end{array}$ & $\begin{array}{c}0.008 \\
(0.016)\end{array}$ & $\begin{array}{c}0.132 \\
(0.021)\end{array}$ & $\begin{array}{c}0.054 \\
(0.055)\end{array}$ & $\begin{array}{c}0.108 \\
(0.096)\end{array}$ \\
\hline $\begin{array}{l}\text { log Maximum } \\
\text { Welfare B enefits }\end{array}$ & $\begin{array}{c}0.077 \\
(0.253)\end{array}$ & $\begin{array}{l}-0.012 \\
(0.399)\end{array}$ & $\begin{array}{c}0.100 \\
(0.109)\end{array}$ & $\begin{array}{c}0.250 \\
(0.123)\end{array}$ & $\begin{array}{c}0.117 \\
(0.044)\end{array}$ & $\begin{array}{c}0.168 \\
(0.042)\end{array}$ & $\begin{array}{c}0.142 \\
(0.118)\end{array}$ & $\begin{array}{c}0.160 \\
(0.184)\end{array}$ \\
\hline $\begin{array}{l}\text { Female } \\
\text { Unemployment Rate }\end{array}$ & $\begin{array}{l}-0.036 \\
(0.012)\end{array}$ & $\begin{array}{l}-0.030 \\
(0.016)\end{array}$ & $\begin{array}{c}0.001 \\
(0.006)\end{array}$ & $\begin{array}{l}-0.010 \\
(0.006)\end{array}$ & $\begin{array}{l}-0.002 \\
(0.003)\end{array}$ & $\begin{array}{l}-0.012 \\
(0.002)\end{array}$ & $\begin{array}{l}-0.023 \\
(0.006)\end{array}$ & $\begin{array}{l}-0.023 \\
(0.008)\end{array}$ \\
\hline State Trends & No & Yes & No & Yes & No & Yes & No & Yes \\
\hline
\end{tabular}

Notes: All specifications include measures of border state abortion policies and are weighted by the population of women aged 15 to 17 in each state and year. Also see notes to Table 4 . 
Table 6: Impact of Changes in Abortion and Welfare Policies and Economic Conditions

on Abortion, Birth, and Pregnancy Rates - Women Age 18-19 (robust standard errors reported in parentheses)

\begin{tabular}{|c|c|c|c|c|c|c|c|c|}
\hline \multirow[b]{2}{*}{ Parental Involvement } & \multicolumn{2}{|c|}{ Abortion Rate } & \multicolumn{2}{|c|}{ Birth Rate - AGI Years } & \multicolumn{2}{|c|}{ Birth Rate - All Years } & \multicolumn{2}{|c|}{ Pregnancy Rate } \\
\hline & $\begin{array}{l}-0.070 \\
(0.032)\end{array}$ & $\begin{array}{l}-0.037 \\
(0.037)\end{array}$ & $\begin{array}{l}-0.020 \\
(0.017)\end{array}$ & $\begin{array}{l}-0.001 \\
(0.017)\end{array}$ & $\begin{array}{l}-0.025 \\
(0.006)\end{array}$ & $\begin{array}{c}0.003 \\
(0.008)\end{array}$ & $\begin{array}{l}-0.039 \\
(0.016)\end{array}$ & $\begin{array}{l}-0.011 \\
(0.020)\end{array}$ \\
\hline Mandatory Delay & $\begin{array}{c}0.006 \\
(0.061)\end{array}$ & $\begin{array}{c}0.096 \\
(0.065)\end{array}$ & $\begin{array}{l}-0.015 \\
(0.019)\end{array}$ & $\begin{array}{l}-0.025 \\
(0.024)\end{array}$ & $\begin{array}{l}-0.010 \\
(0.010)\end{array}$ & $\begin{array}{c}0.006 \\
(0.008)\end{array}$ & $\begin{array}{l}-0.003 \\
(0.027)\end{array}$ & $\begin{array}{c}0.014 \\
(0.028)\end{array}$ \\
\hline $\begin{array}{l}\text { Welfare Waiver } \\
\text { Implemented }\end{array}$ & $\begin{array}{l}-0.099 \\
(0.049)\end{array}$ & $\begin{array}{l}-0.017 \\
(0.068)\end{array}$ & $\begin{array}{c}0.011 \\
(0.032)\end{array}$ & $\begin{array}{l}-0.141 \\
(0.031)\end{array}$ & $\begin{array}{c}0.019 \\
(0.014)\end{array}$ & $\begin{array}{l}-0.066 \\
(0.015)\end{array}$ & $\begin{array}{l}-0.055 \\
(0.029)\end{array}$ & $\begin{array}{l}-0.074 \\
(0.033)\end{array}$ \\
\hline Family Cap & $\begin{array}{c}0.130 \\
(0.078)\end{array}$ & $\begin{array}{c}0.092 \\
(0.128)\end{array}$ & $\begin{array}{l}-0.040 \\
(0.054)\end{array}$ & $\begin{array}{c}0.145 \\
(0.054)\end{array}$ & $\begin{array}{l}-0.037 \\
(0.022)\end{array}$ & $\begin{array}{c}0.094 \\
(0.020)\end{array}$ & $\begin{array}{c}0.060 \\
(0.044)\end{array}$ & $\begin{array}{c}0.133 \\
(0.055)\end{array}$ \\
\hline $\begin{array}{l}\text { log Maximum } \\
\text { Welfare B enefits }\end{array}$ & $\begin{array}{c}0.193 \\
(0.146)\end{array}$ & $\begin{array}{c}0.091 \\
(0.254)\end{array}$ & $\begin{array}{c}0.083 \\
(0.082)\end{array}$ & $\begin{array}{c}0.033 \\
(0.088)\end{array}$ & $\begin{array}{c}0.043 \\
(0.035)\end{array}$ & $\begin{array}{c}0.021 \\
(0.035)\end{array}$ & $\begin{array}{c}0.162 \\
(0.079)\end{array}$ & $\begin{array}{c}0.106 \\
(0.123)\end{array}$ \\
\hline $\begin{array}{l}\text { Female } \\
\text { Unemployment Rate }\end{array}$ & $\begin{array}{l}-0.027 \\
(0.008)\end{array}$ & $\begin{array}{l}-0.031 \\
(0.012)\end{array}$ & $\begin{array}{l}-0.009 \\
(0.004)\end{array}$ & $\begin{array}{l}-0.008 \\
(0.004)\end{array}$ & $\begin{array}{l}-0.003 \\
(0.002)\end{array}$ & $\begin{array}{l}-0.004 \\
(0.002)\end{array}$ & $\begin{array}{l}-0.021 \\
(0.004)\end{array}$ & $\begin{array}{l}-0.021 \\
(0.005)\end{array}$ \\
\hline State Trends & No & Yes & No & Yes & No & Yes & No & Yes \\
\hline
\end{tabular}

Notes: All specifications include measures of border state abortion policies and are weighted by the population of women aged 18 and 19 in each state and year. Also see notes to Table 4 . 
Table 7: Impact of Changes in Abortion and Welfare Policies and Economic Conditions on Abortion, Birth, and Pregnancy Rates - Women Age 20-44 (robust standard errors reported in parentheses)

\begin{tabular}{|c|c|c|c|c|c|c|c|c|}
\hline \multirow[b]{2}{*}{ Parental Involvement } & \multicolumn{2}{|c|}{ Abortion Rate } & \multicolumn{2}{|c|}{ Birth Rate - AGI Years } & \multicolumn{2}{|c|}{ Birth Rate - All Years } & \multicolumn{2}{|c|}{ Pregnancy Rate } \\
\hline & $\begin{array}{l}-0.036 \\
(0.032)\end{array}$ & $\begin{array}{l}-0.045 \\
(0.050)\end{array}$ & $\begin{array}{l}-0.005 \\
(0.009)\end{array}$ & $\begin{array}{c}0.001 \\
(0.007)\end{array}$ & $\begin{array}{l}-0.016 \\
(0.005)\end{array}$ & $\begin{array}{l}-0.003 \\
(0.004)\end{array}$ & $\begin{array}{l}-0.011 \\
(0.010)\end{array}$ & $\begin{array}{l}-0.007 \\
(0.010)\end{array}$ \\
\hline Mandatory Delay & $\begin{array}{l}-0.038 \\
(0.046)\end{array}$ & $\begin{array}{c}0.007 \\
(0.082)\end{array}$ & $\begin{array}{l}-0.038 \\
(0.012)\end{array}$ & $\begin{array}{l}-0.024 \\
(0.013)\end{array}$ & $\begin{array}{l}-0.013 \\
(0.007)\end{array}$ & $\begin{array}{l}-0.002 \\
(0.005)\end{array}$ & $\begin{array}{l}-0.030 \\
(0.013)\end{array}$ & $\begin{array}{l}-0.012 \\
(0.019)\end{array}$ \\
\hline $\begin{array}{l}\text { Welfare Waiver } \\
\text { Implemented }\end{array}$ & $\begin{array}{l}-0.043 \\
(0.048)\end{array}$ & $\begin{array}{l}-0.023 \\
(0.055)\end{array}$ & $\begin{array}{l}-0.005 \\
(0.013)\end{array}$ & $\begin{array}{l}-0.033 \\
(0.017)\end{array}$ & $\begin{array}{l}-0.007 \\
(0.007)\end{array}$ & $\begin{array}{l}-0.026 \\
(0.007)\end{array}$ & $\begin{array}{l}-0.015 \\
(0.019)\end{array}$ & $\begin{array}{l}-0.029 \\
(0.020)\end{array}$ \\
\hline Family Cap & $\begin{array}{c}0.118 \\
(0.081)\end{array}$ & $\begin{array}{c}0.028 \\
(0.116)\end{array}$ & $\begin{array}{c}0.041 \\
(0.025)\end{array}$ & $\begin{array}{c}0.050 \\
(0.023)\end{array}$ & $\begin{array}{c}0.047 \\
(0.012)\end{array}$ & $\begin{array}{c}0.051 \\
(0.010)\end{array}$ & $\begin{array}{c}0.059 \\
(0.029)\end{array}$ & $\begin{array}{c}0.064 \\
(0.030)\end{array}$ \\
\hline $\begin{array}{l}\log \text { Maximum } \\
\text { Welfare B enefits }\end{array}$ & $\begin{array}{c}0.350 \\
(0.157)\end{array}$ & $\begin{array}{c}0.249 \\
(0.200)\end{array}$ & $\begin{array}{c}0.146 \\
(0.046)\end{array}$ & $\begin{array}{c}0.052 \\
(0.037)\end{array}$ & $\begin{array}{c}0.119 \\
(0.027)\end{array}$ & $\begin{array}{c}0.058 \\
(0.021)\end{array}$ & $\begin{array}{c}0.210 \\
(0.054)\end{array}$ & $\begin{array}{c}0.127 \\
(0.060)\end{array}$ \\
\hline $\begin{array}{l}\text { Female } \\
\text { Unemployment Rate }\end{array}$ & $\begin{array}{l}-0.013 \\
(0.009)\end{array}$ & $\begin{array}{c}0.000 \\
(0.009)\end{array}$ & $\begin{array}{l}-0.006 \\
(0.002)\end{array}$ & $\begin{array}{l}-0.005 \\
(0.002)\end{array}$ & $\begin{array}{l}-0.005 \\
(0.001)\end{array}$ & $\begin{array}{l}-0.007 \\
(0.001)\end{array}$ & $\begin{array}{l}-0.010 \\
(0.003)\end{array}$ & $\begin{array}{l}-0.005 \\
(0.002)\end{array}$ \\
\hline State Trends & No & Yes & No & Yes & No & Yes & No & Yes \\
\hline
\end{tabular}

Notes: All specifications include measures of border state abortion policies and are weighted by the population of women aged 18 and 19 in each state and year. Also see notes to Table 4 . 
Table 8: Impact of Changes in Abortion and Welfare Policies and Economic Conditions on the Log Number of Births, by Level of Educational Attainment and Marital Status of Mother (robust standard errors reported in parentheses)

\begin{tabular}{|c|c|c|c|c|c|c|c|c|}
\hline \multirow[b]{3}{*}{$\begin{array}{l}\text { Parental } \\
\text { Involvement }\end{array}$} & \multicolumn{2}{|c|}{ HS Dropout } & \multicolumn{2}{|c|}{ HS Graduate } & \multicolumn{2}{|c|}{ Some College } & \multicolumn{2}{|c|}{ College Grad } \\
\hline & \multicolumn{8}{|c|}{ Unmarried Women } \\
\hline & $\begin{array}{l}-0.012 \\
(0.013)\end{array}$ & $\begin{array}{c}0.019 \\
(0.011)\end{array}$ & $\begin{array}{l}-0.031 \\
(0.010)\end{array}$ & $\begin{array}{l}-0.005 \\
(0.008)\end{array}$ & $\begin{array}{c}0.005 \\
(0.017)\end{array}$ & $\begin{array}{l}-0.005 \\
(0.012)\end{array}$ & $\begin{array}{l}-0.027 \\
(0.021)\end{array}$ & $\begin{array}{l}-0.018 \\
(0.019)\end{array}$ \\
\hline Mandatory Delay & $\begin{array}{l}-0.009 \\
(0.017)\end{array}$ & $\begin{array}{c}0.015 \\
(0.012)\end{array}$ & $\begin{array}{l}-0.010 \\
(0.015)\end{array}$ & $\begin{array}{c}0.018 \\
(0.011)\end{array}$ & $\begin{array}{l}-0.019 \\
(0.021)\end{array}$ & $\begin{array}{l}-0.016 \\
(0.014)\end{array}$ & $\begin{array}{c}0.013 \\
(0.029)\end{array}$ & $\begin{array}{c}0.003 \\
(0.026)\end{array}$ \\
\hline $\begin{array}{l}\text { Welfare Waiver } \\
\text { Implemented }\end{array}$ & $\begin{array}{c}0.002 \\
(0.016)\end{array}$ & $\begin{array}{c}0.030 \\
(0.018)\end{array}$ & $\begin{array}{l}-0.035 \\
(0.020)\end{array}$ & $\begin{array}{l}-0.038 \\
(0.015)\end{array}$ & $\begin{array}{l}-0.083 \\
(0.035)\end{array}$ & $\begin{array}{c}0.003 \\
(0.017)\end{array}$ & $\begin{array}{l}-0.022 \\
(0.044)\end{array}$ & $\begin{array}{l}-0.029 \\
(0.024)\end{array}$ \\
\hline Family Cap & $\begin{array}{c}0.021 \\
(0.023)\end{array}$ & $\begin{array}{c}0.026 \\
(0.023)\end{array}$ & $\begin{array}{c}0.011 \\
(0.031)\end{array}$ & $\begin{array}{c}0.064 \\
(0.022)\end{array}$ & $\begin{array}{c}0.109 \\
(0.046)\end{array}$ & $\begin{array}{c}0.007 \\
(0.022)\end{array}$ & $\begin{array}{l}-0.003 \\
(0.051)\end{array}$ & $\begin{array}{l}-0.010 \\
(0.036)\end{array}$ \\
\hline $\begin{array}{l}\log \text { Maximum } \\
\text { Welfare Benefits }\end{array}$ & $\begin{array}{c}0.202 \\
(0.057)\end{array}$ & $\begin{array}{c}0.165 \\
(0.049)\end{array}$ & $\begin{array}{c}0.139 \\
(0.045)\end{array}$ & $\begin{array}{c}0.083 \\
(0.044)\end{array}$ & $\begin{array}{c}0.010 \\
(0.084)\end{array}$ & $\begin{array}{c}0.117 \\
(0.070)\end{array}$ & $\begin{array}{c}0.021 \\
(0.095)\end{array}$ & $\begin{array}{c}0.239 \\
(0.095)\end{array}$ \\
\hline \multirow[t]{2}{*}{$\begin{array}{l}\text { Female } \\
\text { Unemployment Rate }\end{array}$} & $\begin{array}{c}0.002 \\
(0.003)\end{array}$ & $\begin{array}{c}0.000 \\
(0.003)\end{array}$ & $\begin{array}{c}0.002 \\
(0.002)\end{array}$ & $\begin{array}{l}-0.001 \\
(0.002)\end{array}$ & $\begin{array}{c}0.005 \\
(0.004)\end{array}$ & $\begin{array}{c}0.006 \\
(0.003)\end{array}$ & $\begin{array}{l}-0.003 \\
(0.005)\end{array}$ & $\begin{array}{l}-0.005 \\
(0.004)\end{array}$ \\
\hline & \multicolumn{8}{|c|}{ Married Women } \\
\hline $\begin{array}{l}\text { Parental } \\
\text { Involvement }\end{array}$ & $\begin{array}{l}-0.027 \\
(0.017)\end{array}$ & $\begin{array}{c}0.014 \\
(0.013)\end{array}$ & $\begin{array}{l}-0.024 \\
(0.009)\end{array}$ & $\begin{array}{l}-0.010 \\
(0.005)\end{array}$ & $\begin{array}{c}0.002 \\
(0.012)\end{array}$ & $\begin{array}{l}-0.002 \\
(0.009)\end{array}$ & $\begin{array}{l}-0.007 \\
(0.008)\end{array}$ & $\begin{array}{l}-0.014 \\
(0.005)\end{array}$ \\
\hline Mandatory Delay & $\begin{array}{c}0.007 \\
(0.029)\end{array}$ & $\begin{array}{c}0.001 \\
(0.019)\end{array}$ & $\begin{array}{l}-0.038 \\
(0.013)\end{array}$ & $\begin{array}{c}0.007 \\
(0.008)\end{array}$ & $\begin{array}{l}-0.030 \\
(0.016)\end{array}$ & $\begin{array}{l}-0.020 \\
(0.010)\end{array}$ & $\begin{array}{c}0.012 \\
(0.013)\end{array}$ & $\begin{array}{c}0.004 \\
(0.007)\end{array}$ \\
\hline $\begin{array}{l}\text { Welfare Waiver } \\
\text { Implemented }\end{array}$ & $\begin{array}{c}0.189 \\
(0.040)\end{array}$ & $\begin{array}{c}0.077 \\
(0.024)\end{array}$ & $\begin{array}{l}-0.024 \\
(0.014)\end{array}$ & $\begin{array}{l}-0.008 \\
(0.009)\end{array}$ & $\begin{array}{l}-0.046 \\
(0.011)\end{array}$ & $\begin{array}{l}-0.022 \\
(0.011)\end{array}$ & $\begin{array}{c}0.025 \\
(0.012)\end{array}$ & $\begin{array}{l}-0.029 \\
(0.009)\end{array}$ \\
\hline Family Cap & $\begin{array}{l}-0.056 \\
(0.049)\end{array}$ & $\begin{array}{l}-0.018 \\
(0.029)\end{array}$ & $\begin{array}{c}0.076 \\
(0.025)\end{array}$ & $\begin{array}{c}0.014 \\
(0.015)\end{array}$ & $\begin{array}{c}0.120 \\
(0.026)\end{array}$ & $\begin{array}{c}0.051 \\
(0.017)\end{array}$ & $\begin{array}{l}-0.016 \\
(0.016)\end{array}$ & $\begin{array}{c}0.030 \\
(0.013)\end{array}$ \\
\hline $\begin{array}{l}\log \text { Maximum } \\
\text { Welfare Benefits }\end{array}$ & $\begin{array}{c}0.062 \\
(0.063)\end{array}$ & $\begin{array}{c}0.083 \\
(0.062)\end{array}$ & $\begin{array}{c}0.187 \\
(0.041)\end{array}$ & $\begin{array}{c}0.030 \\
(0.032)\end{array}$ & $\begin{array}{c}0.044 \\
(0.045)\end{array}$ & $\begin{array}{l}-0.026 \\
(0.042)\end{array}$ & $\begin{array}{c}0.032 \\
(0.041)\end{array}$ & $\begin{array}{l}-0.003 \\
(0.029)\end{array}$ \\
\hline $\begin{array}{l}\text { Female } \\
\text { Unemployment Rate }\end{array}$ & $\begin{array}{l}-0.010 \\
(0.004)\end{array}$ & $\begin{array}{l}-0.004 \\
(0.003)\end{array}$ & $\begin{array}{l}-0.003 \\
(0.002)\end{array}$ & $\begin{array}{l}-0.004 \\
(0.001)\end{array}$ & $\begin{array}{l}-0.012 \\
(0.003)\end{array}$ & $\begin{array}{l}-0.001 \\
(0.002)\end{array}$ & $\begin{array}{l}-0.008 \\
(0.003)\end{array}$ & $\begin{array}{l}-0.001 \\
(0.002)\end{array}$ \\
\hline State Trends & No & Yes & No & Yes & No & Yes & No & Yes \\
\hline
\end{tabular}

Notes: Estimates for married and unmarried women in each educational category represent the results from separate regression models for each group. All specifications are weighted by the population of women aged 15 to 44 in each state and year. They each include state and year fixed effects along with the percentage of women in each 5 year age bracket among those between 15 and 44, and the log of the number of women 15 to 44 in the state. Welfare policies that were introduced in the middle of the year are coded as the fraction of the year in which they existed. All policy variables and economic conditions are lagged one year from the date of the outcome. The data employed for these regressions includes only those states that indicated marital status directly on the birth certificate throughout the sample period. The states excluded are: California, Connecticut, Maryland, Michigan, Montana, Nevada, New York, Ohio, and Texas. In addition, the state of Washington (along with California, New York and Texas) does not include educational attainment of the mother on their birth certificate throughout the sample period, so it was excluded as well. 
Table 9: Impact of Changes in Abortion and Welfare Policies and Economic Conditions on the Log Number of Births for Unmarried Women without a High School Degree, by Birth Order (robust standard errors reported in parentheses)

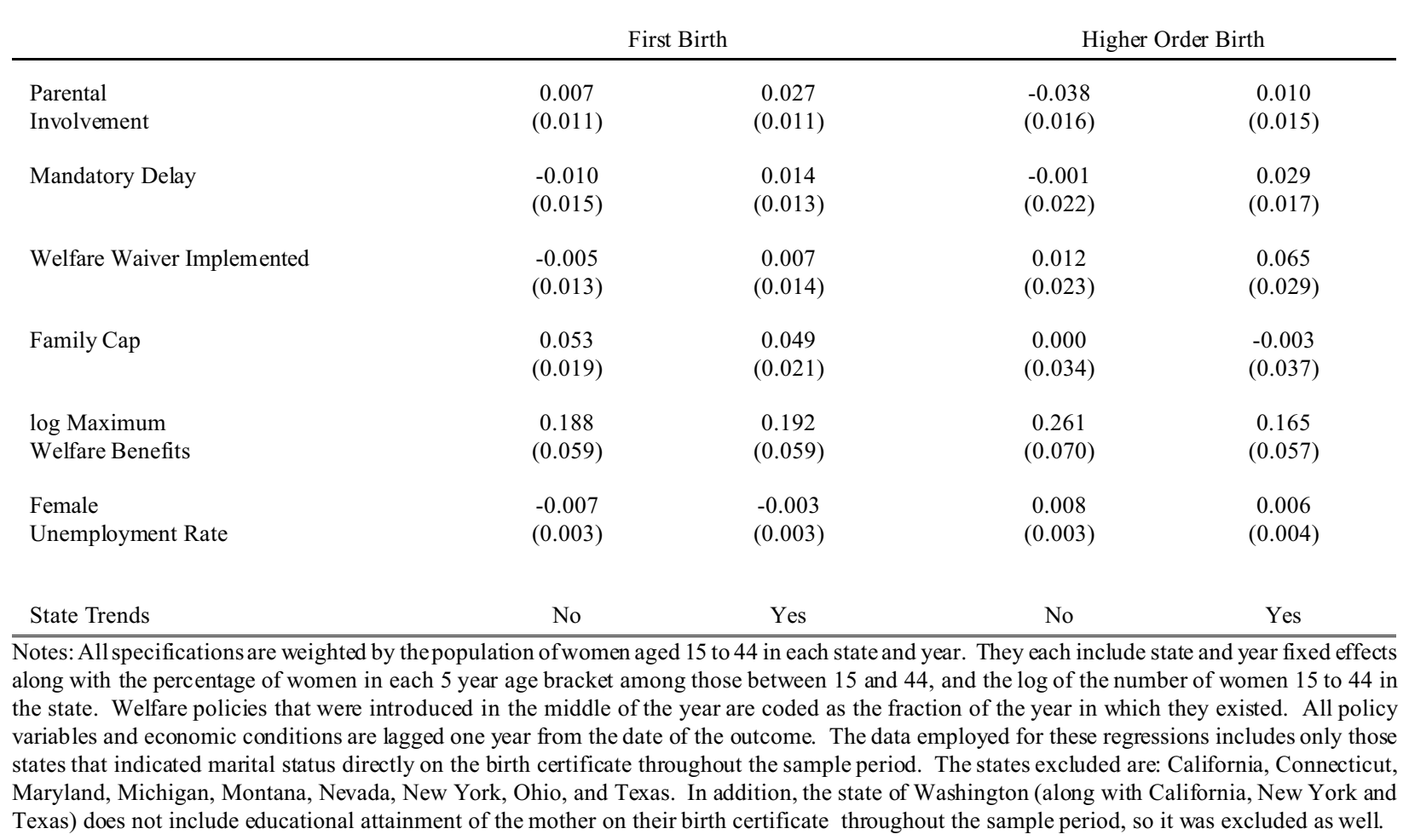


Table 10: Impact of Changes in Social Policies and Economic Conditions on the Likelihood of Unprotected Sexual Activity,

Selected Population Subgroups

(robust standard errors reported in parentheses)

Unmarried Women

\begin{tabular}{|c|c|c|c|c|c|c|c|c|c|}
\hline & \multirow[b]{2}{*}{$\begin{array}{c}\text { All } \\
\text { Women }\end{array}$} & \multirow[b]{2}{*}{$\begin{array}{c}\text { Unmarried } \\
\text { Women }\end{array}$} & \multirow[b]{2}{*}{ Age $15-18$} & \multirow[b]{2}{*}{ Age 19-24 } & \multirow[b]{2}{*}{ Age $25-44$} & \multirow[b]{2}{*}{$\begin{array}{c}\leq \mathrm{HS} \\
\text { Degree }\end{array}$} & \multirow[b]{2}{*}{$\begin{array}{l}\geq \text { Some } \\
\text { College }\end{array}$} & \multicolumn{2}{|c|}{$\leq$ HS Degree } \\
\hline & & & & & & & & $\begin{array}{c}\text { no } \\
\text { children }\end{array}$ & $\geq 1$ child \\
\hline Parental Involvement Law & $\begin{array}{l}-0.007 \\
(0.017)\end{array}$ & $\begin{array}{c}0.003 \\
(0.019)\end{array}$ & $\begin{array}{l}-0.059 \\
(0.034)\end{array}$ & $\begin{array}{c}0.032 \\
(0.038)\end{array}$ & $\begin{array}{c}0.018 \\
(0.029)\end{array}$ & $\begin{array}{l}-0.021 \\
(0.026)\end{array}$ & $\begin{array}{c}0.033 \\
(0.027)\end{array}$ & $\begin{array}{l}-0.042 \\
(0.033)\end{array}$ & $\begin{array}{c}0.009 \\
(0.043)\end{array}$ \\
\hline Mandatory Delay Law & $\begin{array}{c}0.017 \\
(0.020)\end{array}$ & $\begin{array}{c}0.044 \\
(0.022)\end{array}$ & $\begin{array}{c}0.068 \\
(0.035)\end{array}$ & $\begin{array}{l}-0.016 \\
(0.046)\end{array}$ & $\begin{array}{c}0.051 \\
(0.036)\end{array}$ & $\begin{array}{c}0.070 \\
(0.031)\end{array}$ & $\begin{array}{c}0.017 \\
(0.035)\end{array}$ & $\begin{array}{c}0.042 \\
(0.037)\end{array}$ & $\begin{array}{c}0.140 \\
(0.051)\end{array}$ \\
\hline $\begin{array}{l}\text { Welfare Waiver } \\
\text { Implemented }\end{array}$ & $\begin{array}{c}0.029 \\
(0.016)\end{array}$ & $\begin{array}{c}0.009 \\
(0.019)\end{array}$ & $\begin{array}{l}-0.021 \\
(0.037)\end{array}$ & $\begin{array}{c}0.019 \\
(0.035)\end{array}$ & $\begin{array}{c}0.027 \\
(0.029)\end{array}$ & $\begin{array}{c}0.015 \\
(0.026)\end{array}$ & $\begin{array}{c}0.000 \\
(0.028)\end{array}$ & $\begin{array}{c}0.014 \\
(0.033)\end{array}$ & $\begin{array}{c}0.021 \\
(0.043)\end{array}$ \\
\hline Family Cap & $\begin{array}{l}-0.046 \\
(0.030)\end{array}$ & $\begin{array}{l}-0.012 \\
(0.039)\end{array}$ & $\begin{array}{l}-0.044 \\
(0.069)\end{array}$ & $\begin{array}{c}0.035 \\
(0.081)\end{array}$ & $\begin{array}{l}-0.031 \\
(0.053)\end{array}$ & $\begin{array}{l}-0.022 \\
(0.054)\end{array}$ & $\begin{array}{c}0.020 \\
(0.049)\end{array}$ & $\begin{array}{l}-0.058 \\
(0.063)\end{array}$ & $\begin{array}{l}-0.021 \\
(0.090)\end{array}$ \\
\hline $\begin{array}{l}\log \text { Maximum } \\
\text { Welfare B enefits }\end{array}$ & $\begin{array}{l}-0.076 \\
(0.095)\end{array}$ & $\begin{array}{l}-0.000 \\
(0.107)\end{array}$ & $\begin{array}{l}-0.084 \\
(0.195)\end{array}$ & $\begin{array}{c}0.231 \\
(0.220)\end{array}$ & $\begin{array}{l}-0.089 \\
(0.153)\end{array}$ & $\begin{array}{c}0.023 \\
(0.149)\end{array}$ & $\begin{array}{l}-0.051 \\
(0.140)\end{array}$ & $\begin{array}{l}-0.050 \\
(0.179)\end{array}$ & $\begin{array}{c}0.052 \\
(0.256)\end{array}$ \\
\hline $\begin{array}{l}\text { Female } \\
\text { Unemployment Rate }\end{array}$ & $\begin{array}{l}-0.004 \\
(0.004)\end{array}$ & $\begin{array}{l}-0.009 \\
(0.004)\end{array}$ & $\begin{array}{c}0.007 \\
(0.008)\end{array}$ & $\begin{array}{l}-0.023 \\
(0.009)\end{array}$ & $\begin{array}{l}-0.009 \\
(0.006)\end{array}$ & $\begin{array}{l}-0.013 \\
(0.006)\end{array}$ & $\begin{array}{l}-0.002 \\
(0.006)\end{array}$ & $\begin{array}{l}-0.011 \\
(0.008)\end{array}$ & $\begin{array}{l}-0.014 \\
(0.011)\end{array}$ \\
\hline Sample Size & 19,150 & 9,893 & 2,027 & 2,545 & 5,285 & 6,263 & 3,630 & 3,099 & 3,164 \\
\hline
\end{tabular}

Notes: All estimates are obtained from weighted linear probability models that include the following additional explanatory variables: an indicator variable for being married (in model estimated for all women), age and age squared, number of children (except in model estimated for women with less than a high school degree and no children), indicator variables for being white, non-Hispanic and non-white, non-Hispanic, years of education, an indicator variable for rural residence, an indicator variable for catholic religion, mother's level of education, variables indicating whether respondent's mother worked full-time or part-time while the respondent was growing up, and state and year of survey indicator variables. The indicator policy variables (parental involvement, mandatory delay, reformed welfare system, and family cap) are lagged one year to insure that the policy is in effect at the time decisions are being made. 
Table 11: Impact of Changes in Social Policies and Economic Conditions on the Likelihood of Sexual Activity,

Selected Population Subgroups

(robust standard errors reported in parentheses)

\begin{tabular}{|c|c|c|c|c|c|c|c|c|c|}
\hline & \multirow[b]{3}{*}{ All Women } & \multirow[b]{3}{*}{$\begin{array}{c}\text { Unmarried } \\
\text { Women }\end{array}$} & \multicolumn{7}{|c|}{ Unmarried Women } \\
\hline & & & \multirow[b]{2}{*}{ Age $15-18$} & \multirow[b]{2}{*}{ Age $19-24$} & \multirow[b]{2}{*}{ Age $25-44$} & \multirow[b]{2}{*}{$\begin{array}{c}\leq \mathrm{HS} \\
\text { Degree }\end{array}$} & \multirow[b]{2}{*}{$\begin{array}{l}\geq \text { Some } \\
\text { College }\end{array}$} & \multicolumn{2}{|c|}{$\leq$ HS Degree } \\
\hline & & & & & & & & $\begin{array}{c}\text { no } \\
\text { children }\end{array}$ & $\geq 1$ child \\
\hline Parental Involvement Law & $\begin{array}{c}0.028 \\
(0.016)\end{array}$ & $\begin{array}{c}0.050 \\
(0.031)\end{array}$ & $\begin{array}{l}-0.013 \\
(0.063)\end{array}$ & $\begin{array}{c}0.120 \\
(0.056)\end{array}$ & $\begin{array}{c}0.050 \\
(0.043)\end{array}$ & $\begin{array}{c}0.032 \\
(0.038)\end{array}$ & $\begin{array}{c}0.062 \\
(0.050)\end{array}$ & $\begin{array}{c}0.072 \\
(0.052)\end{array}$ & $\begin{array}{l}-0.042 \\
(0.052)\end{array}$ \\
\hline Mandatory Delay Law & $\begin{array}{l}-0.008 \\
(0.020)\end{array}$ & $\begin{array}{c}0.001 \\
(0.037)\end{array}$ & $\begin{array}{c}0.079 \\
(0.072)\end{array}$ & $\begin{array}{l}-0.119 \\
(0.064)\end{array}$ & $\begin{array}{c}0.025 \\
(0.055)\end{array}$ & $\begin{array}{c}0.005 \\
(0.046)\end{array}$ & $\begin{array}{l}-0.011 \\
(0.062)\end{array}$ & $\begin{array}{l}-0.027 \\
(0.059)\end{array}$ & $\begin{array}{c}0.094 \\
(0.071)\end{array}$ \\
\hline $\begin{array}{l}\text { Welfare Waiver } \\
\text { Implemented }\end{array}$ & $\begin{array}{l}-0.019 \\
(0.015)\end{array}$ & $\begin{array}{l}-0.041 \\
(0.029)\end{array}$ & $\begin{array}{l}-0.100 \\
(0.057)\end{array}$ & $\begin{array}{l}-0.055 \\
(0.054)\end{array}$ & $\begin{array}{c}0.028 \\
(0.041)\end{array}$ & $\begin{array}{l}-0.032 \\
(0.037)\end{array}$ & $\begin{array}{l}-0.061 \\
(0.047)\end{array}$ & $\begin{array}{l}-0.034 \\
(0.050)\end{array}$ & $\begin{array}{c}0.010 \\
(0.051)\end{array}$ \\
\hline Family Cap & $\begin{array}{l}-0.001 \\
(0.030)\end{array}$ & $\begin{array}{c}0.020 \\
(0.055)\end{array}$ & $\begin{array}{c}0.113 \\
(0.106)\end{array}$ & $\begin{array}{c}0.052 \\
(0.103)\end{array}$ & $\begin{array}{l}-0.100 \\
(0.074)\end{array}$ & $\begin{array}{c}0.044 \\
(0.065)\end{array}$ & $\begin{array}{l}-0.011 \\
(0.096)\end{array}$ & $\begin{array}{c}0.098 \\
(0.089)\end{array}$ & $\begin{array}{l}-0.088 \\
(0.083)\end{array}$ \\
\hline $\begin{array}{l}\log \text { Maximum } \\
\text { Welfare B enefits }\end{array}$ & $\begin{array}{c}0.204 \\
(0.096)\end{array}$ & $\begin{array}{c}0.330 \\
(0.167)\end{array}$ & $\begin{array}{c}0.006 \\
(0.329)\end{array}$ & $\begin{array}{c}0.611 \\
(0.340)\end{array}$ & $\begin{array}{c}0.233 \\
(0.225)\end{array}$ & $\begin{array}{c}0.345 \\
(0.204)\end{array}$ & $\begin{array}{c}0.237 \\
(0.276)\end{array}$ & $\begin{array}{c}0.429 \\
(0.284)\end{array}$ & $\begin{array}{c}0.018 \\
(0.271)\end{array}$ \\
\hline $\begin{array}{l}\text { Female } \\
\text { Unemployment Rate }\end{array}$ & $\begin{array}{c}0.003 \\
(0.004)\end{array}$ & $\begin{array}{c}0.007 \\
(0.005)\end{array}$ & $\begin{array}{c}0.000 \\
(0.014)\end{array}$ & $\begin{array}{c}0.015 \\
(0.013)\end{array}$ & $\begin{array}{l}-0.001 \\
(0.010)\end{array}$ & $\begin{array}{c}0.003 \\
(0.009)\end{array}$ & $\begin{array}{c}0.011 \\
(0.011)\end{array}$ & $\begin{array}{c}0.001 \\
(0.012)\end{array}$ & $\begin{array}{c}0.008 \\
(0.012)\end{array}$ \\
\hline Sample Size & 19,150 & 9,893 & 2,049 & 2,545 & 5,285 & 6,263 & 3,630 & 3,099 & 3,164 \\
\hline
\end{tabular}

Notes: See notes to Table 10. 
Table 12: Impact of Changes in Social Policies and Economic Conditions on the Likelihood of Failure to Use Contraception at Last Intercourse,

Selected Population Subgroups

(robust standard errors reported in parentheses)

\begin{tabular}{|c|c|c|c|c|c|c|c|c|c|}
\hline & \multirow[b]{3}{*}{ All Women } & \multirow[b]{3}{*}{$\begin{array}{l}\text { Unmarried } \\
\text { Women }\end{array}$} & \multicolumn{7}{|c|}{ Unmarried Women } \\
\hline & & & \multirow[b]{2}{*}{ Age $15-18$} & \multirow[b]{2}{*}{ Age $19-24$} & \multirow[b]{2}{*}{ Age 25-44 } & \multirow[b]{2}{*}{$\begin{array}{c}\leq \mathrm{HS} \\
\text { Degree }\end{array}$} & \multirow[b]{2}{*}{$\begin{array}{l}\geq \text { Some } \\
\text { College }\end{array}$} & \multicolumn{2}{|c|}{$\leq$ HS Degree } \\
\hline & & & & & & & & $\begin{array}{c}\text { no } \\
\text { children }\end{array}$ & $\geq 1$ child \\
\hline Parental Involvement Law & $\begin{array}{l}-0.018 \\
(0.020)\end{array}$ & $\begin{array}{l}-0.012 \\
(0.031)\end{array}$ & $\begin{array}{l}-0.165 \\
(0.088)\end{array}$ & $\begin{array}{c}0.010 \\
(0.053)\end{array}$ & $\begin{array}{c}0.009 \\
(0.042)\end{array}$ & $\begin{array}{l}-0.052 \\
(0.043)\end{array}$ & $\begin{array}{c}0.036 \\
(0.043)\end{array}$ & $\begin{array}{l}-0.131 \\
(0.068)\end{array}$ & $\begin{array}{c}0.022 \\
(0.052)\end{array}$ \\
\hline Mandatory Delay Law & $\begin{array}{c}0.029 \\
(0.025)\end{array}$ & $\begin{array}{c}0.072 \\
(0.041)\end{array}$ & $\begin{array}{c}0.100 \\
(0.109)\end{array}$ & $\begin{array}{c}0.002 \\
(0.072)\end{array}$ & $\begin{array}{c}0.077 \\
(0.056)\end{array}$ & $\begin{array}{c}0.113 \\
(0.054)\end{array}$ & $\begin{array}{c}0.022 \\
(0.061)\end{array}$ & $\begin{array}{c}0.058 \\
(0.085)\end{array}$ & $\begin{array}{c}0.168 \\
(0.062)\end{array}$ \\
\hline $\begin{array}{l}\text { Welfare Waiver } \\
\text { Implemented }\end{array}$ & $\begin{array}{c}0.045 \\
(0.020)\end{array}$ & $\begin{array}{c}0.036 \\
(0.032)\end{array}$ & $\begin{array}{c}0.011 \\
(0.097)\end{array}$ & $\begin{array}{c}0.036 \\
(0.053)\end{array}$ & $\begin{array}{c}0.037 \\
(0.044)\end{array}$ & $\begin{array}{c}0.057 \\
(0.043)\end{array}$ & $\begin{array}{c}0.010 \\
(0.047)\end{array}$ & $\begin{array}{c}0.033 \\
(0.072)\end{array}$ & $\begin{array}{c}0.041 \\
(0.053)\end{array}$ \\
\hline Family Cap & $\begin{array}{l}-0.067 \\
(0.038)\end{array}$ & $\begin{array}{l}-0.050 \\
(0.061)\end{array}$ & $\begin{array}{l}-0.217 \\
(0.175)\end{array}$ & $\begin{array}{c}0.028 \\
(0.111)\end{array}$ & $\begin{array}{l}-0.029 \\
(0.076)\end{array}$ & $\begin{array}{l}-0.083 \\
(0.082)\end{array}$ & $\begin{array}{c}0.049 \\
(0.082)\end{array}$ & $\begin{array}{l}-0.205 \\
(0.128)\end{array}$ & $\begin{array}{l}-0.013 \\
(0.105)\end{array}$ \\
\hline $\begin{array}{l}\log \text { Maximum } \\
\text { Welfare B enefits }\end{array}$ & $\begin{array}{l}-0.166 \\
(0.123)\end{array}$ & $\begin{array}{l}-0.090 \\
(0.186)\end{array}$ & $\begin{array}{l}-0.047 \\
(0.573)\end{array}$ & $\begin{array}{c}0.197 \\
(0.327)\end{array}$ & $\begin{array}{l}-0.216 \\
(0.246)\end{array}$ & $\begin{array}{l}-0.003 \\
(0.249)\end{array}$ & $\begin{array}{l}-0.204 \\
(0.283)\end{array}$ & $\begin{array}{l}-0.341 \\
(0.410)\end{array}$ & $\begin{array}{c}0.164 \\
(0.308)\end{array}$ \\
\hline $\begin{array}{l}\text { Female } \\
\text { Unemployment Rate }\end{array}$ & $\begin{array}{l}-0.006 \\
(0.005)\end{array}$ & $\begin{array}{l}-0.016 \\
(0.007)\end{array}$ & $\begin{array}{c}0.010 \\
(0.022)\end{array}$ & $\begin{array}{l}-0.032 \\
(0.013)\end{array}$ & $\begin{array}{l}-0.014 \\
(0.009)\end{array}$ & $\begin{array}{l}-0.021 \\
(0.010)\end{array}$ & $\begin{array}{l}-0.007 \\
(0.010)\end{array}$ & $\begin{array}{l}-0.024 \\
(0.016)\end{array}$ & $\begin{array}{l}-0.019 \\
(0.013)\end{array}$ \\
\hline Sample Size & 15,284 & 6,192 & 711 & 1,785 & 3,681 & 3,964 & 2,228 & 1,372 & 2,592 \\
\hline
\end{tabular}

Notes: See notes to Table 10 . 
Figure 1: Changes in Abortion and Welfare Laws at the State Level, 1985 to 1995

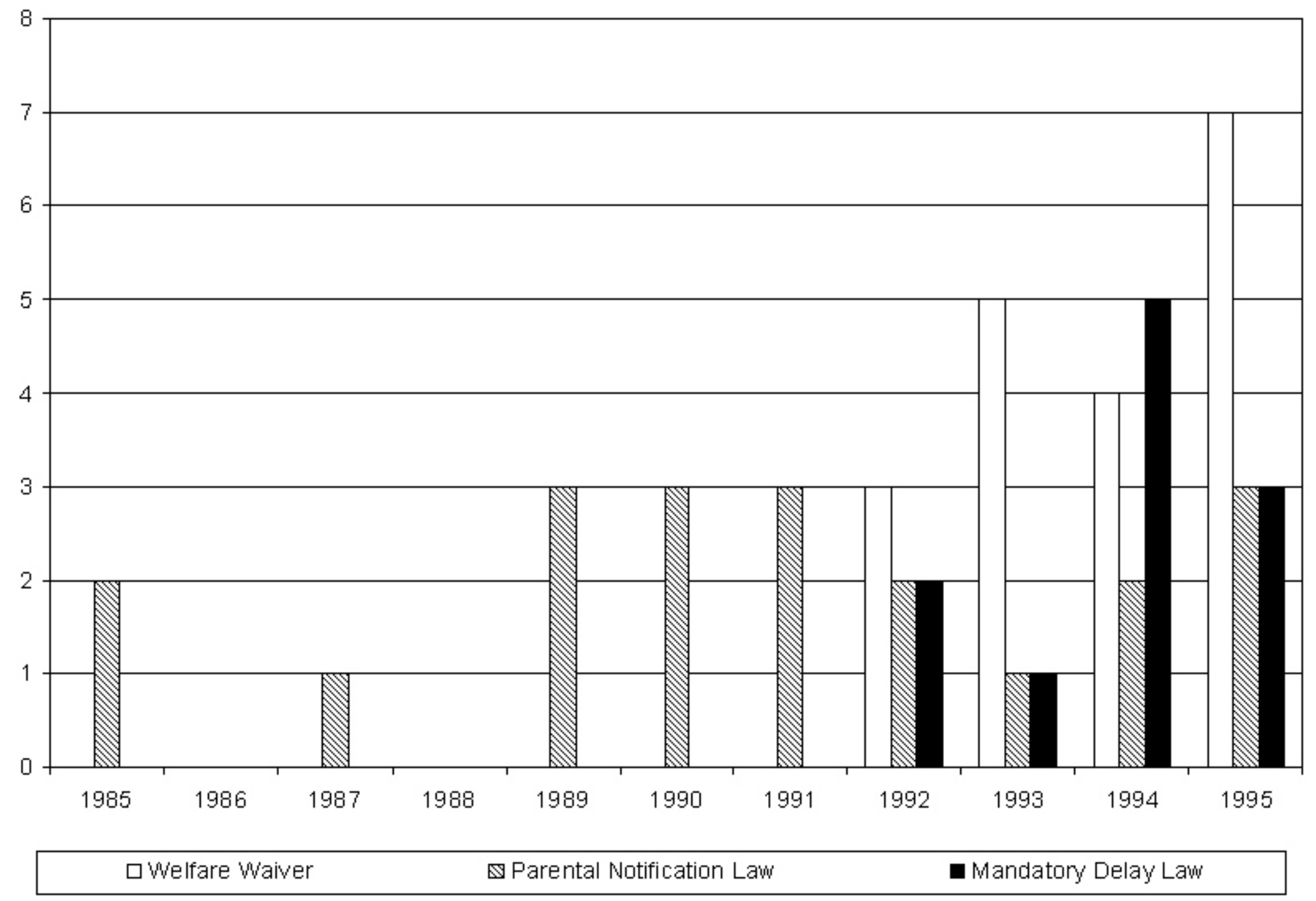

